\title{
Oinarrizko Errenta Unibertsala: errealitatea ala fikzioa?
}

\section{Maialen San Sebastian Kortajarena}

Bergarako Udala

<maialenss@gmail.com>

Artikulu honetan aztertzen da Eusko Jaurlaritzak martxan jarri dituen Oinarrizko Errentek arazo sozialei erantzun eraginkor bat proposatzea lortu ote duten. Horretarako, alde batetik oinarrizko errentak EAEn izan duen bilakaera, bere testuinguru politiko, ekonomiko eta soziala kontuan hartuz ikertu da. Bestetik, beste herrialde batzuetako egoera eta ereduak landu dira, beste herrialde batzuetan eta beste eredu batzuekin nola funtzionatu den eta zein emaitza lortu diren ikusteko. Kontuan izanik indarrean dagoen eta egon den oinarrizko errentaren ereduarekin ez dela lortu asistentzia sistema eta aktibazio sistema batetik haratago joatea, erantzun egoki bat emateko bidean Oinarrizko Errenta Unibertsala bidea izan daitekeen garatu da.

\section{GAKO-HITZAK:}

Dirulaguntzak, Oinarrizko Errenta, Oinarrizko Errenta Unibertsala, kritika.
En este artículo se estudia si la renta básica propuesta por el Gobierno Vasco ha logrado dar una respuesta eficaz a los problemas sociales. Para ello, por un lado se ha analizado su evolución, teniendo en cuenta el contexto social, económico y político. Por otro lado, se han estudiado las situaciones y los modelos de otros países para ver cómo funcionan o han funcionado, y los resultados obtenidos.

Considerando que con el modelo vigente de renta básica no se ha conseguido ir más allá de un sistema de atención y activación, la renta básica universal puede representar una alternativa adecuada.

\section{PALABRAS CLAVE:}

Prestaciones económicas, renta básica, renta básica universal, crítica 


\section{Sarrera}

Oinarrizko errenta, 1986ko pobreziaren inguruko inkestak erakutsitako emaitzei erantzun bat emateko sortu zen, hau da, bazterkeria egoerei erantzun bat eman ahal izateko. Ordutik, ia 30 urte igaro dira, eta Euskal Autonomia Erkidegoan lege eta politika ezberdinak egon dira indarrean arazo sozial honi erantzun ahal izateko. Indarrean dagoen eta egon den oinarrizko errentaren ereduarekin ez da lortu asistentzia eta aktibazio sistema batetik haratago joatea. Aurrera eraman den politikaren gabeziak direla eta, (gizarteratzea ez da eskubide eta betebehar moduan ulertzen, pertsonaren aktibazioa ez du bermatzen, pobreziaren eta bazterketaren arazoari oinarritik heldu beharrean asistentzia arloko erantzun bat ematen du, etab.) bazterketa eta pobreziaren egoerari ez zaio erabateko erantzuna eman.

Jarraian aurkezten den artikuluaren helburu nagusia da hurrengo galderari erantzutea: 1989az geroztik Eusko Jaurlaritzak martxan jarri duen Oinarrizko Errentak, moldaketa eta egokitzapenak ezagutu dituela jakinik, lortu ahal du behartasunak eta bazterketa sozialak irudikatzen dituen arazo sozialei erantzun eraginkor bat proposatzea? Horretarako, lehenik ezagutu behar da zein testuingurutan kokatzen garen, eta ondoren marko honek dituen eta izan dituen gabeziak aztertuko dira. Azkenik, egoera honi erantzuteko aukerak proposatuko dira, erantzun egoki bat lortu ahal izateko bidean Oinarrizko Errenta Unibertsalaren rola zein izan daitekeen aztertuz.

\section{Oinarrizko errenta}

\subsection{Oinarrizko errenten ezaugarriak}

Oinarrizko errentaren ildoan, definizio ezberdinak topa ditzakegu, hala nola:

- Oinarrizko errentak, prestazio ekonomikoak dira, eta pertsonak bizi ahal izateko gutxiengo ekonomiko bat izatea helburu dute; babes sozialaren gutxiengo maila markatzen dute (Milano, 1990).

- Baliabide eta tresna ezberdinez eratutako neurria, eta gutxiengo bizibide eta gizarteratzeko minimo batzuek hornituko dira, euren kabuz sortu ezin dituzten pertsonentzako (Moreno, 2000: 62).

- Azkeneko babes sistema eta segurtasun ekonomikoa. Estatuak transferentzia ekonomikoak egingo dizkie familiei, izaera bereizgarria izango dute, eta baliabideen egiaztatzeari lotua egongo da. Baldintza zehatz batzuk betetzean eta ohikoak diren prestazio sozialetarako (langabezia saria, pentsioak, etab.) eskubidea ez izatean onartuko dira (Noguera eta Ubasart, 2003).

- Pertsona edo familia guztiek duten eskubidea, lan merkatuan eta gizarte bizitzan gizarteratu ahal izateko eta oinarrizko beharrak asetzeko, gutxiengo bat bermatua izateko gizarteratze prozesuan zehar.
Definizio ezberdinak topatu arren, ezaugarri komunak ere erakusten dituzte (Euzéby, 1991: 95-96):

- Orokorrean, programa hauek asistentziaren arloan kokatzen dira eta euren helburua gutxiengo ekonomiko batzuk bermatzea eta pertsonaren gizarteratzea lortzea da.

- Gizarte segurantza sistemaren osagarri gisa funtzionatzen dute. Baliabide ekonomiko eskasak dituzten pertsonentzat, segurtasunaren azkeneko sare gisa funtzionatzen dute.

- Baldintzatuta daude. Oinarrizko errenta lortu ahal izateko baldintza batzuk bete behar dira (adina, errolda, konpromisoak, etab.).

- Eskubide gisa definitu arren, zenbait herrialdetan egoera ekonomikoari lotuta dago eta honen arabera, mugak ezartzen dira.

- Prestazioa jasotzeko eskubidea normalean ez da egoten denboran mugatua.

\subsection{Oinarrizko errenten bilakaera}

Oinarrizko errentak 9o. hamarkadan eratu zirela dirudien arren, XX. mendearen erdialdean, zenbait Estatutan diru sarrera gutxiengo batzuk bermatzera zuzenduriko neurriak sortu ziren. Hala ere, 80. hamarkadatik aurrera eratu ziren gaur egun ezagutzen ditugun oinarrizko errentak; laguntza ekonomikoaz gain, gizarteratzea bultzatu nahi dute.

Hasierako oinarrizko errentetara itzultzen bagara, langabezia apaleko eta garapen handiko Europa batean aurkituko gara. Testuinguru honetan, oinarrizko errentak, prestazio sozialen barnean beste prestazio bat bezala azaltzen dira, eta bere izaera guztiz ekonomikoa da. Helburu nagusia da biztanleriari gutxiengo ekonomiko batzuk bermatzea.

1970-1990 artean eman zen krisi ekonomikoak, langabezia tasaren igoera bat ekarri zuen, eta honi lotuta, pobrezia egoeren gorakada. Hori dela eta, oinarrizko errentei loturiko balorazio soziala guztiz aldatu zen, eta horrek, politika publikoak aldatzea bultzatu zuen.

Hasierako laguntza prestazioari egiten zitzaion kritika hurrengoa zen:

- Alde batetik, prestazio honen onuradunak diren pertsonak, mendekotasun horretara egokitzen dira, eta, ondorioz, egoera horretatik ateratzen lagundu beharrean, horrela geratzea bultzatzen du.

- Beste aldetik, programa honen finantziazioa ahalbidetzen duen gizarte zatiarentzat, garestiak direnaren pentsamendua nagusitzen da, eta euren garapen ekonomikoa baldintzatzen duela.

Kritika hauen ostean, asistentzia programen erreforma bat etorri zen. Zentzu honetan, lanaren balioaren handitze bat egin zen eta ongizatea lortu 
ahal izateko oinarrizko osagai bihurtu zen. Horrela, prestazio ekonomikoa eta gizarteratzea partekatzen dituen eredu bat eratu zen. Filosofia berri hau, Europar Batasuneko 92/411 Aholkuan, babes sozialeko sistemaren baliabide eta prestazioei buruzko oinarrizko irizpideen ingurukoan islatzen da. Aholku honek, bazterketa sozialaren aurkako borroka bultzatzen du eta duintasunean bizi ahal izateko pertsonek baliabide eta Estatuak prestazioetarako duten eskubidea onartzera bultzatzen ditu.

Eskubide honen aitortza, ondorengo printzipio komun hauei jarraituz egin dezatela aholkatzen du:

- Pertsonaren duintasunean oinarritutako eskubidea da.

- Baliabide nahikorik ez duten pertsonei onartuko zaie.

- Lan adina duten pertsonek eta osasun edo familia baldintzekin uztartzen duten pertsonek, eskubidearen onarpena lan eskaintzak onartzearekin lotura izango dute.

- Ez du epe mugarik izango.

- Onuradunen gizarteratze ekonomiko eta soziala bultzatzen duten neurriekin lotuta egon beharko luke.

Aholku honetan, Estatu kideei eskubide hau hurrengo pausoak jarraituz onartu dezatela eskatzen zaie:

- Oinarrizko errentaren gutxieneko kopuruak, bizikidetza unitate motaren eta tamainaren arabera erabakiko dira, kontuan hartuz herrialde horretako bizitza maila.

- Kopuru osagarriak ezartzeko aukera egongo da, behar zehatzak ase ahal izateko.

- Adierazle egokiak azterturik erabakiko dira laguntzaren kopuruak, hau da, kontsumo familiarreko estatistikak, lanbide arteko gutxieneko soldata, prezio maila, etab.

- Aldizkako berrikuspen arauak ezarriko dira, prozedura administratiboak sinplifikatuko dira eta errekurtsoak jartzeko aukera emango da.

- Lan bilaketarako pizgarriak mantenduko dira.

- Laguntza ekonomikoa osagarria izango da, eta familiaren diru sarreren eta beharrak asetzeko ezarrita dagoen gutxiengoaren arteko aldea aseko du.

Orokorrean, Europan gailendu den ereduak, gutxiengo batzuk bermatuko dituen sistema unibertsal edo ia unibertsalak onartzen ditu baina eskubide hau, beti gizarteratze printzipioari lotuta egongo da. Horrela, diru sarrera minimo batzuk jasotzeko eskubidea, gizarteratze prozesu bati lotuta egon da. Ideia honen helburua da prestazioarekiko mendekotasunarekin apurtzea eta egoera horretatik ahalik eta azkarren ateratzeko baliabideak eskaintzea.

Hala ere, maila teorikoan puntu honetan egon arren eta Europar Batasunaren norabidea zentzu honetan izan arren, ez dago legedi komun bat Estatu guztientzat eta beraz, bakoitzak bere legedi propioa du bere baldintza, ezaugarri eta estrategiekin.

Azkenik, beharrezkoa da azpimarratzea, egungo joerei jarraiturik, pobrezia eta bazterkeriaren aurkako politikak ondorengo moduan ezaugarritzen direla:

- Babes ekonomiko mugatuko eredua, bizirautera orientatuta, laguntza osagarri mugatuak, eta prestazioen sarrerarako epe zehatz batean emateko betekizuna dute.

- Onuradunaren betebeharrak indartuko dira. Betebehar berriak, lanerako sarrera sustatzera bideratuko dira, prestazio ekonomikorako eskubidea gizarteratzeko kontratu bat izenpetzea behartuta egotearekin lotuz.

- Enplegurako zeharkako pizgarriak. Honekin, diru sarrera apaleko lanen errentagarritasuna hobetu nahi da.

- Ekintzen deszentralizazioa.

\subsection{Oinarrizko errentak Espainian}

Azterketa honetan aurrera eginez, orokortasunetik zehaztasunera igarotzen joango gara. Hori dela eta, behin Europako egoera aztertu ostean, Espainia mailara igaroko gara.

Espainia mailan, babes sozialaz hitz egiten denean, hurrengoari egiten zaio erreferentzia (Martínez Torres, 2004): pertsonen edo familien oinarrizko beharrak estaltzen direla bermatzeko erabiltzen den tresna.

Ildo honi jarraituz eta estaldura hori bermatu ahal izateko, bi sistema mota sortzen dira:

1. Gizarte Segurantza: gizarteak, bere kideei eskaintzen dien babesa hainbat neurri publikoren bidez, muga ekonomiko eta sozialei aurre egiteko. Neurri hauek eskainiko ez balira, diru sarrerak gutxitzea edo desagertzea emango litzateke gaixotasun, amatasun, lan istripu, langabezia, elbarritasun, zahartzaro eta heriotza kasuetan. Gainera, laguntza medikua eta seme alabak dituzten familiei babes laguntza ere eskaintzen die.

2. Gizarte laguntza: gizarte segurantzatik kanpo dagoen babes sistema da. Premia egoera zehatzei aurre egiteko babes sistema moduan agertzen da. Gizarte laguntzaren oinarrizko ezaugarriak unibertsaltasuna, premia egoera frogatu beharra eta izaera subsidiarioa dira.

Horrela, administrazio publiko ezberdinek prestazio ekonomikoak ondorengo hiru maila osagarri hauetan antolatu dituzte:

1. Gizarte Segurantzaren barruan aurkitzen diren prestazio ekonomikoak (langabezia saria, kontribuzio pentsioa, etab.). 


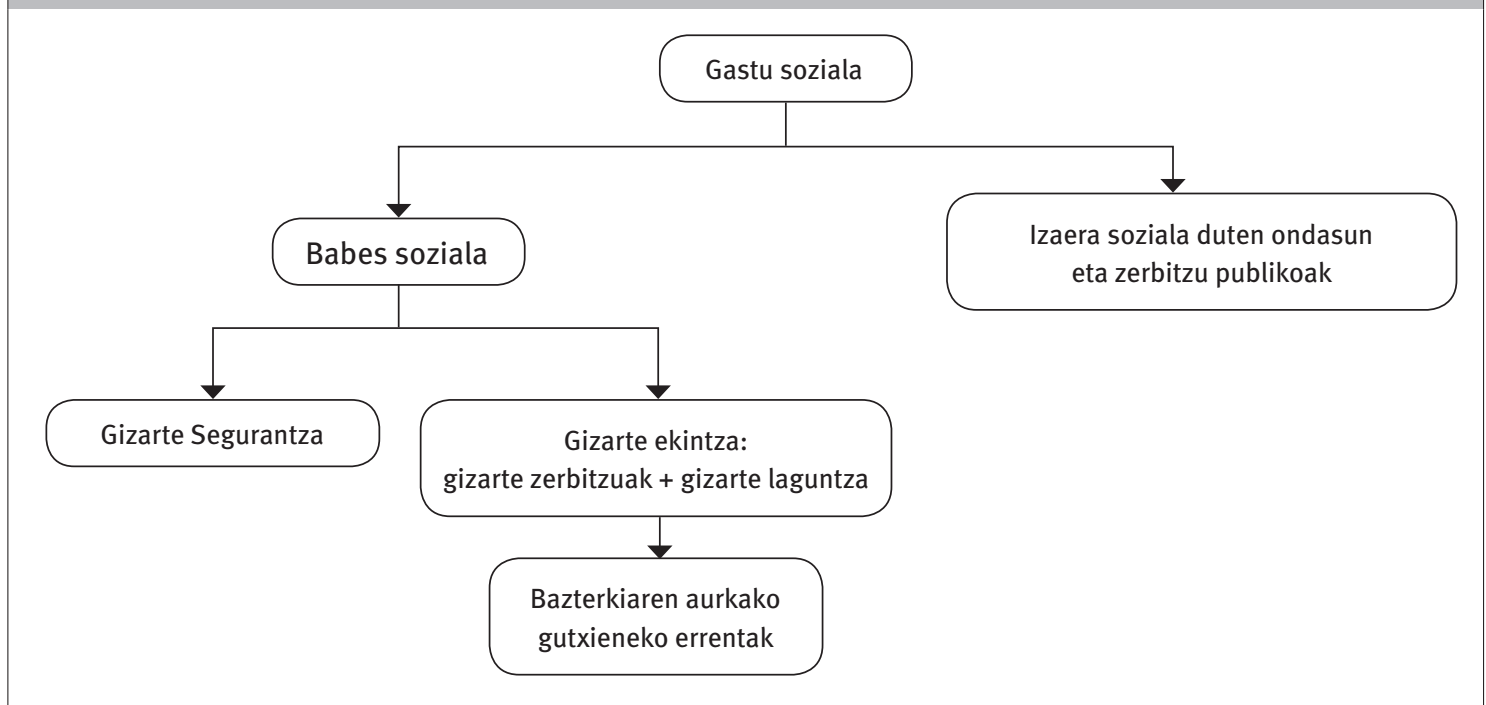

Iturria: Martínez Torres (2004), egileak itzulita.

2. Gizarte Segurantzaren luzapenak diren prestazio ekonomikoak (kontribuzio gabeko pentsio, langabezia dirulaguntzak, etab.).

3. Maila autonomikoan eta lokalean ematen diren prestazio ekonomikoak (orokor edo espezializatuak).

Behin maila hauek zehaztuta, Estatuko administrazioak Gizarte Segurantzaren barruan kokatzen diren prestazioen bidez bermatuko ditu premia espezifikoak, eta, aldiz, bazterkeriaren aurkako babes orokorra geratuko da Autonomia Erkidegoen esku¹.

1. irudiaren bidez, errazago ulertuko dugu non kokatzen diren bazterketa sozialaren aurkako programak gastu sozialaren barnean.

Espainian, bazterkeriaren aurka lan egiteko programen artean hurrengoak aurkitzen dira: gutxieneko errentak, gizarte zerbitzuak, gizarte segurantzako laguntza prestazioak, etab. Beraz, gizarteratzeko edo bazterkeriaren aurkako gutxieneko errentak azken neurri gisa kokatzen dira, eta autonomia erkidegoen eskumen bezala kokatzen dira.

Azken sistema honen barruan, aldizkako errentak nahiz egoera zehatzei aurre egiteko larrialdietarako laguntzak aurkitzen dira, eta Ayalaren (2000) arabera, oinarrizko lau printzipio hauei jarraitzen die:

1. Elkartasuna: birbanaketa.

2. Gizarteratzea: giza kapitalean inbertsioa.

3. Egituraketa soziala.

4. Eskubide sozialen luzapena: ongizate soziala.

${ }^{1}$ Espainiar konstituzioko 148 eta 149 artikuluetan, Estatuaren eta autonomia erkidegoen eskumenak zehazten dira bakoitzaren eginbeharrak markatuz.
Gutxieneko errentak 9o. hamarkada hasieran jarri ziren martxan, eta EAE izan arren aurrenekoa errenta hauek martxan jartzen, eta, urte gutxitan, autonomia erkidego gehienetara zabaldu zen. Prestazio hauen onarpena ez zen oso ohikoa izan, autonomia erkidegoek eraman baitzuten aurrera, Gobernu zentralaren oposizioarekin. Programa hauen jatorrian ez zen aurkitzen bazterkeriari eta pobreziari aurre egiteko planteamendurik, ez eta horri aurre egiteko hausnarketarik. Orokorrean, maila politiko eta sindikalean ematen ari zen negoziazioari jarraiki onartu ziren, eta, ondorioz, erreferentzia politiko argien falta, komunikabideen ezjakintasuna eta interes falta eta gizartearen ezjakintasuna topatzen ditugu.

Ezberdintasunak egon arren, autonomia erkidego bakoitzak indarrean jarritako oinarrizko errentetan, orokorrean denak eredu frantsesari jarraitzen diote, eta eskubide bikoitz honetan oinarritzen da: gutxiengo diru sarrera batzuk izateko eskubidea eta gizarteratzeko eskubidea. Hala ere, oinarrizko errentaren moduan jarraitzen duen eredu bakarra EAEkoa dela esan dezakegu, eta atzetik Katalunia, Madril edo Nafarroa aurkituko lirateke. Gainontzeko autonomietan oso zaila da oinarrizko errenta batez hitz egitea, euren babes txikia dela eta, dituzten mugak edo eskubide subjektibo moduan ez ulertzeagatik.

Honela, lau multzo bereizi ditzakegu, baina taula aztertu baino lehen ondorengo kontzeptu hauek argitzea komeni da:

- Oinarrizko errenta: prestazio ekonomikoa gizarteratzeko ekintza batzuei lotuta dago, eta onuradunaren betebeharra izango da ekintza horiek burutzea.

- Lan sozial babestua: lan sozial babestuaz hitz egiten dugunean, workfare filosofiari jarraitzen dioten programez ari gara, hau da, premia 


\begin{tabular}{|l|r|r|}
\hline \multicolumn{2}{|l|}{ 1. koadroa. Oinarrizko errenten inguruko sailkapena } \\
\hline \multicolumn{2}{|c|}{ Oinarrizko errenta programa motak } \\
\hline Programa mota & Oinarrizko errenta & Lan sozial babestua \\
\hline Oinarrizko errenta (zentzu osoan) & Euskal Autonomia Erkidegoa & Nafarroa \\
\hline Oinarrizko errenta (muga batzuekin) & Madril \\
& Katalunia & Asturias \\
& Aragoi & Gaztela Mantxa \\
Araututako babes laguntzak & $\begin{array}{r}\text { Murtia } \\
\text { Errioxa }\end{array}$ & Andaluzia \\
\hline
\end{tabular}

Iturria: Arriba (1999), egileak itzulita.

egoerari erantzuteko lehen neurri moduan erabilera sozialeko aldizkako lan bat eskaintzen da, eta azken neurri moduan onartzen da dirulaguntza edo prestazio ekonomikoa.

- Araututako babes laguntzak: garai bateko pobreentzako babes prestazioekin lotzen dira ez baitute inolako berrikuntzarik orduko sistemarekin alderatuz gero.

Espainia mailako eredu ezberdinak ikusi eta gero, hauen txertaketa denboran zehar nola izan den aztertuko da (Rodríguez Cabrero, 2009).

Aipatu dugun moduan, autonomia erkidegoen artean eredu ezberdinak topa ditzakegu, eta batzuk oinarrizko errentaren eredura beste batzuk baina gehiago gerturatu arren, ezaugarri komun batzuk ematen dira Aguilar, Laparra eta Gaviriak $(1995,1996)$ azaltzen duten moduan:

- Izaera subsidiarioa du.

- Izaera finalista du. Oinarrizko beharrak asetzeko erabili behar da.

- Izaera pertsonala du, beraz, besterenezina da. Ezin dira enbargatu edo betebeharren berme gisa erabili.

- Erreferentzia unitate gisa familia hartzen da.

- Baliabideen urritasuna frogatu behar da prestazioa jaso ahal izateko.

- Onuradunak izan ditzakeen diru sarreren osagarria da.

- Autonomia Erkidegoen artean mugikortasuna ekiditeko mekanismo bat dute.

- Prestazioaren onarpena denbora zehatz baterako izaten da, nahiz eta luzapenak egiteko aukera dagoen.

- Prestazio ekonomikoa gizarteratzeko ekintzei lotua dago.

Hasieran aipatu dugun moduan, Oinarrizko Errentak Espainian ez du izaera unibertsala. Autonomia Erkidego bakoitzak bere legedia izan arren, eta bakoitzak bere baldintzak ezarri arren, denetan topa ditzakegu hurrengo alderdiekin zerikusia duten baldintzak: nazionalitatea, egoitza, adina, bizikidetza unita- tea eta baliabide ekonomikoak, beraz, ezin dugu eskubide unibertsalez garbi hitz egin.

\section{Oinarrizko errenta EAEn}

Oinarrizko errenten inguruko azterketa honetan, maila zehatzenean autonomiak aurkitzen dira kasu honetan, Euskal Autonomia Erkidegoan kokatuz.

\subsection{Pobreziaren eta bazterketa sozialaren egoera}

Pobrezia eta bazterketa sozialaren egoera aztertzen hasi aurretik, kontzeptu hauek argitzea komeni da (Justizia, Lan eta Gizarte Segurantza Saila, 2008: 15 eta 43):

- Pobrezia: dena delako gizarteko ongizateko erdiko mailak dituen ondasun eta zerbitzuak eskuratzeko zailtasuna edo ezintasuna. Pobreziaren barruan hurrengo sailkapena egiten da:

- Mantentze pobrezia: epe motzean erantzun beharreko beharrei (premia arruntei) ihardesteko behar adinako diru sarrerak edo errenta ez izatea.

- Metatze pobrezia: epe ertain eta luzean bizi maila egokia mantentzeko beharrezko kontsumo ondasun iraunkorrak eskuratzeko gai ez izatea (egoera onean eta behar bezala hornituta dagoen etxebizitza, etab.).

- Ezkutuko pobrezia: nork beregaintasuna lortzeko prozesuak oztopatzearen ondorioz, beregaintasuna lortuz gero izango lukeen pobrezia ezkutuan geratzea.

- Bazterketa: gizarte eskubideak gauzatzeko ezintasuna edo gaitasunik eza da, batez ere lan egiteko eskubideaz baliatzeko ezintasuna, baina baita hezkuntza eta prestakuntza jasotzeko eskubidea, kultura, osasuna, etxebizitza duina izateko eskubidea edo gizarte babesa jasotzeko eskubidea ere.

José Felix Tezanosen (2004: 31) arabera ezaugarri hauetan bereizi ohi dira pobrezia eta bazterketa (2. koadroa). 


\begin{tabular}{|c|c|c|}
\hline Bereizgarriak & Pobrezia & Bazterketa \\
\hline Egoera & Egoera & Prozesua \\
\hline Izaera & Pertsonala & Egiturazkoa \\
\hline Subjektuak & Banakakoak & Taldeak \\
\hline Aldeak & Funtsean, bakarra (gabezia ekonomikoa) & $\begin{array}{l}\text { Askotarikoak (lanekoa, ekonomikoa, soziala, } \\
\text { kulturala) }\end{array}$ \\
\hline Esparru historikoa & Gizarte industrialak (edo tradizionalak) & $\begin{array}{l}\text { Industria ondoko gizarteak edota teknologia } \\
\text { arloan aurreratuak }\end{array}$ \\
\hline Analisia egiteko aplika daitekeen ikuspegia & Desbideratzearen soziologia & Gatazkaren soziologia \\
\hline Funtsezko aldagaiak & Kulturalak eta ekonomikoak & Lanekoak \\
\hline Kidetutako gizartearen joerak & Pobretzea & Gizartearen dualizazioa \\
\hline Arrisku gehigarriak & Marjinazioa & Gizartearekiko loturen krisia \\
\hline Alderdi pertsonalak & Porrota, pasibotasuna & Afiliazio eza, erresumina \\
\hline Bilakaera & Hondarrak & Gero eta handiagoa \\
\hline Gizarte barneko distantziak & Goitik beherakoa & Barnetik kanporakoa \\
\hline Eragina duten aldagai ideologiko politikoak & $\begin{array}{l}\text { Laguntza ematearen aldekoa ez den } \\
\text { liberalismoa }\end{array}$ & Arauak haustearen aldeko neoliberalismoa \\
\hline
\end{tabular}

Iturria: Tezanos (2004), egileak itzulita.

Hasieran, bazterketa eta pobrezia kontzeptuak baliokide gisa erabili ziren, baina 1980ko hamarkadatik aurrera Europako Batzordea bazterketa hitza erabiltzen hasi zen pobrezia terminoaren ordez, bazterketa nozioak zentzu zabalagoa duela oharturik.

\subsection{Gizarte zibilaren eskaera eta egoera horren trataera politikoa2}

1973ko krisiaren aurretik, EAEn hazkunde ekonomikoko urteak bizi izan ziren, eta ia ez zegoen langabeziarik. 1984ean, aldiz, \% 22,5ekoa zen. 1970eko hamarkadaren amaiera aldeko eta 1980ko hamarkadaren hasiera aldeko krisiak EAEn ere eragin handia izan zuen, eta hori, Euskadin pobrezia ofizialki aztertzeko lehenengo ahaleginaren testuingurua izan zen. Hain zuzen ere, krisialdiarekin batera langabezia eta pobrezia bezalako fenomenoak birsortu ziren.

Atzeraldi ekonomiko horrek sortutako kezkak administrazioa hainbat neurri hartzera bideratu zuen, hala nola, lan eta heziketa arloko ekintzak eta pobreziaren inguruko ikerketa bat martxan jartzea. Kontuan izan behar da Europa mailan zentzu honetan ari zirela lan egiten, eta une horretan administrazioak horrelako ikerketa bat egiteko dirua zuela. Ikerketa hau kasualitate multzo baten ondorio dela esan daiteke, une horretan ez baitzegoen presio sozialik gai honen inguruan (familiek erantzuten zuten pobrezia egoeretan), eta aurrez ere ez zen azaldu ildo honetan ekintzak martxan jartzeko borondate politikorik. Hala ere, kasualitate horien emaitza izan zen 1986an buruzko azterlana.

${ }^{2}$ Gizarte politikak EAEn laburpena eta taula osatzeko, Sartu Federazioa (2010) erabili dut, eta arlo hau lantzeko Jaione Mondragon (2006).
Azterketa honen berezitasuna pobreziaren dimentsio anitzeko izaera kontuan hartzean datza, eta bertan mantenu pobrezia, metatze pobrezia eta ezkutuko pobrezia bereizten ziren, eta,aldi berean, hauen barruan, pobrezia mailak ezberdintzen zituen.

Azterketaren emaitzek eragin handia izan zuten maila sozialean eta maila politikoan, izan ere, espero ez ziren datuak islatu baitzituen. Datuen arabera, EAEko etxebizitzen $\% 38,5$ pobrezia egoeran aurkitzen zen, horrek zekartzan ondorioekin. Gainera, pobrezia gehien jasaten zuten 65 urtetik gorako pertsonek eta gurasobakarreko familiek (ama eta seme alabek osaturiko familiek).

Lortutako datuen ostean, neurriak hartzea erabaki zen, eta gaia agenda politikoan txertatu zen. Ondorioz, arazoari aurre egiteko kohesio sozialeko programa bat behar zela adostu zuten, eta, horrela, Pobreziaren Aurkako Osoko Plana abian jarri zuten. Ondorengo hiru mailatan egituratu zen Plana:

1. Inolako diru sarrerarik ez duten pertsonei arreta.

2. Gizarte larrialdiko egoerei arreta.

3. Pobreziaren aurkako neurri sektorialen aplikazioa.

Plan honen barnean, orain aztertuko ditugun dispositibo eta neurriak onartu ziren.

\subsection{Familien Gutxiengo Errenta}

Aipatu dugun moduan, Pobreziaren Aurkako Osoko Plana 1988an onartu zuen lehendakariak eta bere gauzatzea 1989ko hasieran eman zen, Familien Gutxiengo Errenta eta Gizarte Larrialdietarako Laguntzen dekretua onartzean. Horrela, 1989ko 
ekainerako bi maila hauek martxan jarri ziren. Dinamika honi jarraituz, 1989ko abuztu amaieran neurri sektorialei zegokion dekretua onartu zen, planaren oinarri juridikoak finkatuz. Ondorengo hiru arazo edo galderei erantzun nahi zitzaien horrela:

- Pobrezia muga bezala ezarrita zegoen kopurutik behera zuten pertsona edo familiei diru sarrera batzuk bermatzea.

- Pobrezia egoeran aurkitzen ziren pertsona edo familiei oinarrizko bizi kalitatean kokatu zitezen diru sarrera bat bermatzea.

- Eusko Jaurlaritzako sail ezberdinek modu koordinatuan ekintza ezberdinak garatzea, ezberdintasunak ekidin eta bazterketa eragiten duten faktore nagusiak ezabatzeko (Raya, 2002).

Dekretuaren zioen adierazpenean agertzen den moduan, ondorengo hiru irizpide nagusiei jarraitzen die:

- Ez da inolaz ere gaur egun dauden gizarteratzeko egitarau ezberdinen ordez egindako egitaraua.

- Bere asmoa ez da talde pasibo berri bat eta egoera hori iraunaraz dezan talde pasibo berri bat sortzea.

- Familiaren gutxienezko diru sarrerak eman behar dizkio hartzekodunari egitarauak, eta bertan egoteko zioak uzteko eta bazterketa egoeratik ateratzeko bidea.

Diru sarrera horiek sendientzat baino ez ziren izango, eta premia egoeran zeuden norbanakoentzako laguntza, gizarte larrialdietarako dirulaguntza egitarauaren edo udaletan zeuden egitarauen babespean utzi ziren.

Beraz, irizpide nagusi horiei jarraituz, dekretuaren xedea hurrengoa zen:

Familiaren gutxienezko diru sarrera izena hartu eta itzultzerik gabeko sorospen izaera ordezkagarria du, eta, behar balitz, indarrean dauden legeetan aurreikusitako noizbehinkako prestazioen osagarria sortzea da; ezarritako baldintzen arabera, bizitzeko premiazkoak diren beharrei erantzuteko diru sarrera nahikorik ez duten sendientzako da, gaur egun duten baztertu egoera uzteko baliagarria izan dadin (39/1989 Dekretua).

Baldintza nagusien artean adina (25 urtetik gorakoa eta 67 urtetik beherakoa izatea) eta errolda (3 urteko errolda EAEko edozein udalerritan) aurkitzen ziren.

Administrazio mailako antolaketari dagokionez, udalei zegokien eskariak jasotzea, espedienteak izapidetzea eta Foru Aldundira bidaltzea zegokion proposamenarekin. Foru Aldundiek diru sarreraren aitortza, ukatzea edo aldatzea, etetea zein indargabetzea eta ordainketak egingo zituzten. Eusko Jaurlaritzak, aldiz, laguntzaren kontrola eta ebaluaketa orokorra egingo zituen.
Dekretu hori onartu eta hurrengo legea onartu bitartean, hiru dekretu eta bi agindu jarri zituen indarrean Eusko Jaurlaritzak, dekretuaren garapena, Gizarte Larrialdietarako Laguntzen araudia edo dekretuaren luzapena, adibidez.

1989 amaieran hurrengo legearen proiektua onartu zen, baina hau indarrean sartu bitartean eta hutsunerik ez egoteko, dekretuaren luzapena burutu zen.

\subsection{Gizarteratzeko Gutxiengo Errenta}

Aurreko atalean azaldu den moduan, 1989 amaieran lege honen proiektua onartu zen, Pobreziaren Aurkako Planaren lehen mailarekin bete ahal izateko, hau da, inolako diru sarrerarik ez duten pertsonei arreta eskaintzeko mailarekin bete ahal izateko.

1990eko maiatzaren 3an, Legebiltzarrak Gizarteratzeko Gutxiengo Errentaren Legea onartu zuen. Lege honek aurreko dekretuaren filosofiarekin jarraitzen zuen. Zioen adierazpenean azaltzen den moduan, Familien Gutxiengo Errentak izandako akats edo hutsuneetatik abiatzen da baina betiere, dirulaguntza horren filosofiari jarraituz. Horrela, diru sarrera horrek, iritzi aurrerakoiak ditu sorburu, gizakienganako errespetuan oinarrituz. Aurreko dirulaguntzarekin alderatuz, ezberdintasunak topa ditzakegu, baina horiek aztertu baino lehen, ikus dezagun dirulaguntzaren ondorengo definizioa:

$$
\begin{aligned}
& \text { Gizarteratzeko Gutxieneko diru sarrera diruzko } \\
& \text { gizarte laguntza gisa eratzen da. Indarrean dau- } \\
& \text { den legeetan ohartematen diren antzeko baliabide } \\
& \text { eta laguntza guztien ordezkoa, eta, hala badago- } \\
& \text { kio, osagarrietakoa izango da. Eman, janaritarako } \\
& \text { eta izendatzen zaion horrentzat bakarrik izango } \\
& \text { da, eta ez du bahikuntzarako gai edo euskarri izan } \\
& \text { beharko, ez eta zorren berme gisara ematerik ere } \\
& \text { izango ( } 2 / 1990 \text { Legea). }
\end{aligned}
$$

Hauek dira bi dirulaguntzen arteko ezberdintasun nagusiak:

- Familien Gutxiengo Errenta izatetik, Gizarteratzeko Gutxiengo Errenta izatera igarotzen da. Lehenengoa, familientzako prestazio ekonomiko bat zen, eta bigarren aldiz, familiez gain, banakako pertsonak artatzera igaro zen, eta familiako kide gisa ez ditu soilik seme alabak hartzen.

- Gizarteratzeko Gutxiengo Errenta ez da soilik asistentzia prestazio bat, egoera kronikoak ekidin nahi ditu, eta horretarako dirulaguntzak lan eta heziketa ekintzekin lotzen ditu.

Legea onartu eta hurrengo bi urteetan, dekretu eta agindu bidez garatu ziren, eta indarrean jarri ziren Gizarteratzeko Gutxiengo Errenta eta Gizarte Larrialdietarako Laguntzak. Lehenengoa, aurrez definitu dugu, eta bigarrenak Pobreziaren Aurkako Planak zenbait arlotan sortzen dituen zehaztugabetasuna biltzea zuen helburu. Horrela, metatze pobreziarekin zerikusia duten arloei erantzun nahi zien, hiru 
kontzeptu hauetan dirulaguntzak onartuz: etxebizitzaren mantenu eta alokairu gastuak, etxebizitzaren egokitzapenerako inbertsio gastuak eta larrialdiko gastuak.

Plan Integrala 1988-1992 urteetarako onartu arren urtez urte luzatzen joan zen, eta honekin batera, baita lege eta dekretuak ere. Luzapen hauekin, 1992an egindako ebaluaketa txostena aztertu eta gaiaren inguruan eztabaidatzea bilatzen zen, eta, aldi berean, alderdi politiko ezberdinen artean, aurrera begira landu beharreko ildoei begira adostasunak lortzea.

Luzapen urte hauetan zehar, ez zen inolako neurririk garatu pobreziaren aurka. Aurreko neurri eta legedien aldaketa batzuk eman ziren aurrera, baina 1998 arte ez zen urrats berririk eman.

Aldi honetan, Gizarte Zerbitzuen legea onartu zen, hau da, 5/1996 Legea eta pobreziaren aurka neurri zehatzik ez izan arren, gizarte zerbitzuen plangintza eta antolaketa bat bideratzen zuen, prestazioen, pobreziaren aurkako neurrien eta administrazio ezberdinen arlo operatiboan eraginez.

\subsection{Gizarte Bazterkeriaren Aurkako Legea}

Pobreziaren Aurkako Osoko Planaren hamar urteko ibilbidea kontuan izanik, Eusko Jaurlaritzak Gizarte Bazterkeriaren Aurkako Legea onartu zuen maiatzaren 22an. Zioen adierazpenean azaltzen den moduan, bazterkeria honela definitzen du:

Gizarte bazterkeriaz jardutean, ez gara pobreziaz hitz egiten ari, pobrezia dena delako gizarteko ongizate erdiko mailak dituen ondasun eta zerbitzuak eskuratzeko zailtasuna edo ezintasuna dela uste badugu. Harreman sarearen prekario izaerarekin batera, pobrezia da gizarte bazterkeriaren agerpenik bistakoena, baina ez da gizarte bazterkeriaren muina. Bazterkeria gizarte eskubideak gauzatzeko ezintasuna edo gaitasunik eza $\mathrm{da}$, batez ere lan egiteko eskubideaz baliatzeko ezintasuna, baina baita ere hezkuntza eta prestakuntza jasotzeko eskubidea, kultura, osasuna, etxebizitza duina izateko eskubidea, edo gizarte babesa jasotzeko eskubidea (Gizarte Bazterkeriaren Aurkako 12/1998 Legea).
Definizio honetatik abiatuz, aurreko legearekiko aldaketak ezarri zituen, baina aldaketa horiek kritikak ere jaso zituzten (3. koadroa).

Legeak jarraitutako prozesu juridikoa aztertuz gero, aurrekoaren ildoa jarraitu zuela ikusiko dugu. Bere garapena bi dekreturen bitartez izan zen, eta horietan arautzen ziren Gizarteratzeko Gutxieneko Errenta eta Gizarte Larrialdietarako Laguntzak. Hala ere, azpimarratzekoak diren ondorengo berrikuntza hauek ere eman ziren:

- Gizarteratzeko hitzarmenak arautzen zituen dekretua (1/200o Dekretua) onartu zen. Dekretu honekin, hitzarmenaren inguruko alderdi ezberdinak arautu nahi ziren, adibidez, onuradunaren betebeharrak, hitzarmenetan sar zitezkeen ekintzak edo hitzarmenaren muga. Aldi berean, Gizarteratzeko Hitzarmenak definitu zituen.

- Gizarteratzeko Hitzarmenak programa dokumentuak dira, eta horietan, parte hartzen duten aldeek, ados jarrita, berariazko gizarte ekintza batzuk zehazten dituzte, hain zuzen ere elkarbizitzako unitate ekonomiko independentean bizi diren kideak gizarteratzeko eta lan munduan sartzeko edo horiek baztertuta izateko duten arriskuari aurre hartzeko. Dokumentu irekiak dira eta gizarteratzeko prozesu bat ezartzeko bideratzen dira.

- Gizarteratzeko Gutxieneko Errentaren eta Gizarte Larrialdietarako Laguntzen onuradunei aplikatzekoak diren lanerako pizgarrien agindua (2001eko otsailaren 14 ko Agindua) onartu zen. Honekin, laneko diru sarrerak dituzten pertsonei pizgarri batzuk aplikatzen zaizkie sarreren konputua kalkulatzeko garaian.

- 12/1998 Legeari lau aldaketa aplikatu zitzaizkion dekretu bidez, uneko errealitate eta beharrei egokitzeko.

- 8/200o Legea: gutxieneko diru sarreraren eskubideduna izateko, beharrezkoa da 25 urtetik gorakoa izatea, eta, kasuan kasuko legerian, zahartzaroa dela eta pentsio publikoa eskuratu ahal izateko gutxieneko adina ( 65 urte) baino gutxiago izatea. Egoera hori konpontzeko, 65 baino urte gutxiago izatearen baldintza kendu zen.

\begin{tabular}{|l|l|}
\hline \multicolumn{2}{|l|}{ 3. koadroa. 12/1998 Legearen inguruko hausnarketa } \\
\hline Lege berriak ekarritako aldaketak & Kontrako iritziak \\
\hline Gizarteratzeko Hitzarmenei balio handia ematen zaie. & $\begin{array}{l}\text { Zalantzan jarri ziren hitzarmenak; batez ere, gizarteratzea } \\
\text { eskubide sozial gisa hitzarmenetan oinarrituz eginez gero, kontrol } \\
\text { burokratiko tresna soil bat bihurtuko zela pentsatzen baitzen. }\end{array}$ \\
\hline $\begin{array}{l}\text { Legearen helburua: azken sarea ziurtatzea, gutxieneko oinarri } \\
\text { ekonomikoa bermatzeko. }\end{array}$ & $\begin{array}{l}\text { Eusko Jaurlaritzak pobreziaren ondorioz sortutako arazoak } \\
\text { arintzeko politikei ematen zien lehentasuna, bazterketaren } \\
\text { arrazoiei aurre hartzeko neurririk hartu gabe. }\end{array}$ \\
\hline $\begin{array}{l}\text { Pobrezia eta bazterkeriaren aurkako ekintzak ohiko eskuartze marko } \\
\text { batean kokatzen dira, ezohiko izaera alde batera utziz. }\end{array}$ & $\begin{array}{l}\text { Aurreko neurrien jarraipen bat da, planteamendu berri bat alde } \\
\text { batera uzten duena. }\end{array}$
\end{tabular}

Iturria: Sartu Federazioa (2010). 
- 9/200o Legea: Gizarte Larrialdietarako Laguntzen kudeaketan foru aldundien bitartekaritza kentzea eta zuzenean Eusko Jaurlaritzaren eta udalen artean egitea.

- 4/2003 Legea: oinarrizko errenta eskuratu ahal izateko baldintzetako bat 25 urte baino gehiago izatea da. Baldintza horrek, gazteriaren zati garrantzitsu bat oinarrizko errentaren eskubidetik kanpo uzten du. Ondorioz, beharrezkotzat jo da oinarrizko errenta eskuratu ahal izateko gutxieneko adina 23 urtera jaistea, muga hori hobeto egokitzen baita gazteriaren eta, oro har, gure gizartearen helburuetara.

- 4/2007 Legea: adin muga 23 urtetara jaisteaz gain, salbuespen egoerak egon daitezkeela aurreikusten da. Prestazioaren zenbatekoa kalkulatzeko 10/2000 Legean oinarrituko da araudia, eta Gizarte Larrialdietarako Laguntzei dagokionez, egoerak dirauen artean laguntza jasotzeko eskubidea izango dutela eransten da.

1999-2003 aldiaren ezaugarri nagusia gizarteratze aktiboaren politiken gorakada izan zen. Bide honi bultzada bat emateko, lan gizarteratzearen ildoan ondorengo neurri ezberdin hauek sartu ziren indarrean:

- Lanerako babes neurriak.

- Lanerako pizgarriak.

- Auzolan programa: 199/2002 dekretuak honela definitzen ditu; Laguntza ekonomikoak eta baliabide sozialak arautzen dituen programa da. Helburu nagusia da bazterketa egoerak saihestea eta baliabide pertsonal, sozial edo ekonomiko nahikorik ez duten pertsonei laneratzen laguntzea.

- Gizarteratze enpresak (147/2010 Dekretua eta 4/2011 Dekretua): laneratzeko enpresatzat hartuko dira honako ezaugarri hauek dituzten ondasun edo zerbitzuen ekoizpen egiturak: gizartean baztertuta edo desabantailan dauden taldeak lan merkatuan sartzeko helburua dute, eta, gainera, gizarteratzeko banan banako proiektuak egiten dituzte, ikasketa prozesu egoki baten bidez, eta prozesu horrekin, enpleguaren baldintzak hobetzen laguntzeko trebetasun sozialak, laneko trebetasunak, oinarrizko prestakuntza, laneko kualifikazioa eta merkatuari buruzko ezagupenak barneratzen dituzte.

\subsection{Herritarren Oinarrizko Errenta}

Aldaketa garai honetan, pobrezia eta bazterkeriari aurre egiteko bidean, herri ekimen baten bidez Herritarren Oinarrizko errenta edo Gizarte Eskubideen Agiria onartu zen (10/200o Legea).

Herri ekimen hau 1996ean sortu zen, langabezia tasa $\%$ zoan kokatzen zenean eta estaldurak murritzak zirenean. Egoera honi erantzuteko, Gogoa plataformak bultzatuta (200 herritar elkartek osatutako sarea) gizarte arloa arautzea helburu zuen herri eki- mena sortu zuen eta 83.000 sinadura lortu zituzten. Kontuan izan behar da, une honetan, Eusko Jaurlaritzatik pobrezia eta bazterkeriaren aurkako borrokarako lege berri batean ari zirela lanean.

Herri ekimenetik abiatutako Gizarte Eskubideen Agiriak, hiru printzipio nagusi jarraitzen zituen eta bi proposamen egiten zituen:

\section{- Printzipioak:}

1. Eskubide unibertsalak berrezartzea, batez ere, lan merkatura sartzeko zailtasunak izan eta diru sarrerarik gabe dauden pertsonei.

2. Oinarrizko Errenta baterako eskubidea, lan eskatzaile izan eta topatzen ez dutenentzat.

3. Lan denboraren banaketa, lana eskatzen dutenen artean.

- Proposamenak:

1. Enpleguari buruzkoak: lanerako eskubidea oinarrizkoa izango da; lana funtsezkoa izango da.

2. Oinarrizko Errenta: lagungarria izango da eta ez du izaera unibertsala eta ez da baldintzarik gabea izango. Oinarrizko errenta, Lanbide arteko gutxieneko soldataren parekoa izango da.

3. Herri ekimen honen lorpen nagusienetako bat izan zen mugimendu sindikala bateratzea eta oinarrizko errentaren inguruko eskakizunak bateratzea, baina ez zuen eragin bera lortu administrazio publikoaren mailan. Ekimen hau kontuan hartzea lortu zen eta izapidetza parlamentarioari ekin zion, baina denbora asko behar izan zuen bere onarpenerako eta hasierako lege proposamenetik, onartu zen legera ezberdintasun handiak zeuden (4. koadroa).

10/200o Legeak oinarrizko errenta baterako eskubidea ezarri zuen, baina izaera orokor batekin. Oinarrizko errenta honek Gutxieneko oinarrizko errenta ordezkatzen du, baina azken batean, ez du bere izaera juridikoa aldatzen ezta prestazioaren oinarriak ere. Ondorioz, kontzeptuak argitu beharrean, nahasi besterik ez ditu egiten; lege honek planteatzen duen oinarrizko errenta ezin baita oinarrizko errenta unibertsal batekin bateratu.

\subsection{Dispositiboaren azken erreforma}

Pobreziaren aurkako borrokan, azken hamarkadan indarrean egon da Gizarte Bazterkeriaren Aurkako Legea (1998). Aurrez azaldu den moduan, 2000. urtean herri ekimen baten bidez oinarrizko errenta unibertsal baten lege saiakera bat egon zen, baina azken batean, oinarri sendorik gabeko lege baten onarpen hutsean geratu zen.

Azken hamarkada honetan, 1998ko legeak zituen hutsune eta arazoen inguruan eztabaidatu eta hausnartu izan da eta gogoeta horietatik iritsi da dispositiboaren azken erreforma, hau da, 18/2008 Legea eta bere garapeneko dekretuak. 


\begin{tabular}{|l|l|}
\hline 4. koadroa. Herritarren Oinarrizko Errentaren proposamenaren eta onartutakoaren arteko ezberdintasunak \\
\hline Lege proposamena & $\mathbf{1 0 / 2 0 0 0 \text { legea }}$ \\
\hline $\begin{array}{l}\text { Zioen azalpenean, EAEko langabezia eta pobrezia egoera azaltzen } \\
\text { zuen zenbakitan. }\end{array}$ & Ez ditu zenbaki errealak aipatzen, milaka lagunez hitz egiten du. \\
\hline $\begin{array}{l}\text { Helburua: Euskadiko herritar guztiek lana eta oinarrizko errenta } \\
\text { izateko aukera izan dezaten ziurtatzea. }\end{array}$ & $\begin{array}{l}\text { Helburua: Lan merkatuan sartzea ahalbidetzea eta oinarrizko errenta } \\
\text { bat ziurtatzea. }\end{array}$ \\
\hline $\begin{array}{l}\text { Lana banatzeko politika baten beharra adierazten zuen, ezin } \\
\text { eztabaidatzeko moduan. }\end{array}$ & $\begin{array}{l}\text { Enplegua sustatu beharra aipatzen du Legeak eta, horretarako, } \\
\text { ekintza positiboko neurriak proposatzen ditu funtsean, laneratzeari } \\
\text { bide emateko. }\end{array}$ \\
\hline $\begin{array}{l}\text { Ez zuen xedatzen behar egoera egiaztatzeko inolako agiririk aurkeztu } \\
\text { beharrik. } \\
\text { Oinarrizko errentaren eta lanbide arteko gutxieneko soldataren } \\
\text { zenbatekoa parekatzen zituen. }\end{array}$ & $\begin{array}{l}\text { Oinarrizko errentaren onuradunak mugatzen ditu eta, oinarrizko } \\
\text { errenta eskuratu ahal izateko, eskatzaileek premia egoera egiaztatu } \\
\text { behar dute. } \\
\text { Oinarrizko errentaren zenbatekoa lanbide arteko gutxieneko } \\
\text { soldataren \%75ean kokatzen du. }\end{array}$ \\
\hline Nahitaezkoa? & $\begin{array}{l}\text { Gizarteratzeko eta laneratzeko eskubidea biltzen ditu, eta hura } \\
\text { erabiltzeko Euskadiko administrazio publikoek sustatzen dituzten } \\
\text { gizarteratzeko hitzarmenetan nahitaez parte hartzera behartzen du. }\end{array}$ \\
\hline Oinarrizko errenta unibertsala & $\begin{array}{l}\text { Oinarrizko errentaren esanahia gizarteratzeko gutxieneko diru } \\
\text { sarrerarekin lotzen du. }\end{array}$ \\
\hline
\end{tabular}

Iturria: Sartu Federazioa (2010)

20 urte hauetan, Gizarteratzeko Plan ezberdinak egon dira indarrean, betiere, martxan jarri nahi ziren edo jarri ziren mekanismo guztien artean koherentzia ezartzeko eta neurri aktiboagoak martxan jartzeko. Ildo honetan, 2004ean, Pobreziari eta gizarte desberdintasunei buruzko inkesta egin zen, eta bertan lortutako datuek hainbat neurri hartzea eta aldaketak bultzatzea ekarri zuten (Pobrezia eta Gizarte desberdintasunei buruzko Inkesta, 2004). Inkestako datuen arabera, pobrezia tasak hobera egin zuen epe luzean, baina egonkor bihurtzeko joera hartu zuen. Hori dela eta, hurrengo neurriak jarri ziren martxan:

- 2004an, EAEko gizarte zerbitzuen erabiltzaileen eta profesionalen eskubideen eta betebeharren gutuna eta iradokizunen eta kexen araubidea onartzeko apirilaren 6ko 64/2004 Dekretua onartu zen.

- 2007an, Gizarteratzeko Erakunde arteko II. Plana onartu zen.

- 2008an, Gizarte Zerbitzuei buruzko abenduaren 5eko 12/2008 Legea onartu zen.

- 2008an, Gizarteratzeko eta diru sarrerak bermatzeko abenduaren 23ko 18/2008 Legea onartu zen eta 2010 eta 2011 urtean legea garatzeko dekretuak onartu ziren.

Gizarte zerbitzuen azken lege honek, gizarte zerbitzuen euskal sistemako prestazio eta zerbitzuen katalogoa eta kartera arautzen ditu, eta bertan zehazten da prestazio ekonomikoen arloa. Prestazio hauen barruan kokatzen dira gizarteratzea edota autonomia errazteko eta gizarte larrialdietan erantzuna emateko prestazioak.

Ildo honi jarraituz, 2008ko abenduan, Gizarteratzeko eta diru sarrerak bermatzeko Legea onartu zen bi helburu orokor betetze aldera. Alde batetik, sortu diren premia berriei erantzun egoki bat emateko bitarteko egokienak jartzea, eta, beste aldetik, indarrean dauden tresnetan antzeman diren akatsak edo hutsuneak konpontzea. Horretarako, ondorengo bi berrikuntza nagusi hauek ditu legeak:

1. Diru sarrerak bermatzeko errenta ondorengo bi modutan antolatzea:

- Gizarteratzeko eta gizarte babeserako oinarrizko errenta: lan errentarik ez duten bizikidetza unitateei zuzendua dago. Prestazio ekonomikoarekin batera, laguntza espezifiko batzuk ematen dira gizarteratzen laguntzeko.

- Laneko diru sarrerak osatzeko errenta: laneko errenta izan arren, hileroko sarrerak gizarteratzeko oinarrizko errentaren azpitik geratzen diren bizikidetza unitateei zuzenduta dago. Prestazioarekin batera, lan egoera hobetzen laguntzeko laguntza espezifiko batzuk ematen dira, baita gizarteratzen laguntzeko bestelako laguntza batzuk ere, gizarte zerbitzuek beharrezkoa irizten badiote.

2. Etxebizitza gastuetarako prestazio osagarria eratzea: diru sarrerak bermatzeko errentaren onuradun diren horiei etxebizitza eskuratzeko eta gastuak ordaindu ahal izateko (alokairu kasuetan) laguntza ematea du helburu.

Bi berrikuntza hauez gain, legeak Gizarte Larrialdietarako Laguntzak eta Gizarteratzeko Hitzarmenak ere aipatzen ditu, eta aurrerago dekretuetan garatuko dira.

Adierazi den moduan, lege honen sorburua aurreko akatsak eta ahuleziak zuzentzean datza. Honetarako, aldaketa batzuen premia beharrezkoa zen eta horregatik, aurreko berrikuntzaz gain, hurrengo aldaketak eman ziren:

- Eskubide bikoitzaren printzipioa finkatzea: baliabide ekonomikoak izateko eta laneratzeko eta gizarteratzeko laguntza pertsonalizatua jasotzeko eskubidea, gizarteratzeko hitzarmen 
batean derrigorrez parte hartuz (elkarrekikotasun printzipioa).

- Enpleguaren nagusitasuna gizarteratzeko tresna gisa.

- Gizarte arloko politikak aktibatzea eta enplegua errentagarri egitea.

Aldaketa hauetan ikusten den moduan, gizarteratze aktiboari eta enpleguari berebiziko garrantzia eman nahi zaio, hori dela eta, bi arlo hauei aipamen berezi bat egiteaz gain, prestazio ekonomikoak gizarteratze aktiboaren printzipioarekin batzen ditu.

\section{Dispositiboaren gabeziak}

\subsection{Oinarrizko Errenta ezberdinen ezaugarriak}

Aurreko ataletan landu den moduan, bai Europa mailan bai Espainia mailan ez dago oinarrizko errenta eredu komun bat ezarrita, eta ondorioz, puntu komunak baina baita ezberdintasunak dituzten ereduak aurkitzen dira. Hala ere, eredu hauek dituzten mugak aztertzean, ezaugarri batzuk partekatzen dituztela esan dezakegu, Ayalak (1994) aipatzen duen moduan.

\subsubsection{Muga finantzariak}

Alde batetik, atzerapen ekonomikoek, oinarrizko errenten garapenean mugak ipintzen dituzte, eta ondorioz, babes sistemaren garapen potentziala oztopatzen dute. Horrela, bai kopuru aldetik bai helburuen aldetik ere, mugak egon dira.

Beste aldetik, finantzaketa iturriei dagokionez, ez dago eredu edo patroi komunik, eta horregatik, Estatu bakoitzak bere finantzaketa bideak ditu; Estatua finantzazio bide bakarra izatetik lurralde bakoitzeko administrazioak finantzazio iturri bakarrak izateraino, tartean dauden egoera guztiak baliatuz. Ondorioz, ezberdintasun handiak ematen dira Estatu batetik bestera. Gainera, finantzaketa sistema zentral bat ez egoteak eta prestazioaren mailak ez zehazteak, epe luzera administrazioen zorra handitzea eta defizit publikoa igotzea ekartzen ditu.

\subsubsection{Balizko onuradunengana iristeko zailtasunak}

Programen izaera eta ezaugarriak direla eta, prestazioa ez da iristen balizko onuradun guztietara. Honek bi arazo sortzen ditu: alde batetik, ezberdintasun horizontal bat sortzen da, hau da, antzeko egoeran aurkitzen diren familien artean batzuek prestazioa jasotzen dute eta besteek ez. Beste aldetik, desberdintasun bertikal bat ere ematen da, hau da, prestazioa jaso beharko ez luketen zenbait familiek prestazioa kobratzen dute.

Arazo horien arrazoi edo faktoreak aztertzeko unean, informazio faltaz hitz egiten da, baina arrazoiak haratago doaz. Ondorengo hiru mailatan aztertuko ditugu faktoreak:

- Dirulaguntzen egiturari dagokiona: oinarrizko errenten sistemak egitura konplexua izan ohi du, eta askotan, legeak ez ditu garbi zehazten zeintzuk diren baldintzak eta betebeharrak.

- Administrazioa: zerbitzua batzuetan kontrol sistema moduan erabiltzen da, eta erabiltzaileek ematen zaien tratua desegoki moduan ikusten dute. Gainera, eskaintzen den informazioa eskasa eta kalitate apalekoa dela azaldu ohi dute.

- Onuraduna: jende askok ez daki dirulaguntzen sistema bat dagoela edo ez daki nola dabilen. Honi, estigma sortzearen beldurra gehitu behar zaio eta mendekotasun sentsazioa.

\subsubsection{Gizarteratzeko mugak}

Azken etapako oinarrizko errenten berrikuntza nagusia prestazio ekonomikoa gizarteratzearekin lotzea da. Egoera honek, hala ere, prestazioaren izaera unibertsala edo eskubide izaera zalantzan jartzea dakar, prestazioaren onarpena kontraprestazio bati lotuta baitago.

Gizarteratzearen dispositiboak ere mugak aurkitzen ditu. Aurrez aipatu dugun atzeraldi ekonomikoaren ondorioz, muga finantzariak topatzen dira alde guztietan. Oinarrizko errentei lotutako neurriek berritzaileak eta malguak izan behar dute onuradunen egoera guztiei egokitu ahal izateko eta berez zaila bada horrelako neurriak indarrean jartzea, muga finantzariek are gehiagoan zaildu egiten dute.

\subsubsection{Lan merkatuari begira ezartzen diren pizgarriak}

Ohiko kritiken artean, lan merkatuan txertatzeko pizgarririk ez duela uste izaten da. Ematen diren kopuruak garaiegiak dira, jendeak lan merkatuan sartu nahi izateko, eta ondorioz, lan bilaketan eragin ezkorrak ditu. Kritika edo ikuspegi hau gizartean nahiko hedatua dago.

Behin muga orokorrak ikusita, EAEko dispositiboak zehazki dituen zailtasun edo gabeziak aztertuko dira hurrengo ataletan.

\subsection{Lanera itzultzeko eraginkortasun eskasa}

Behin eta berriz errepikatu da testuan zehar gaur egungo dispositiboaren eredua eta filosofia gizarteratze aktiboaren kontzeptuan oinarritzen dela. Hori dela eta, lehen pausoa gizarteratze aktiboa zer den definitzea izango da:

Politika, neurri eta tresna multzoa, prestazio ekonomikoak jasotzen dituzten langabeak lan merkatuan integratzeko eta horrela haien gizarte eta ekonomia gizarteratzea hobetzeko abian jar- 


\begin{tabular}{|c|c|c|c|c|}
\hline \multicolumn{5}{|c|}{ 5. koadroa. Gizarteratze politika aktiboen arloan dauden politika eta programak } \\
\hline Politika & Ekintza programak & & Helburuak & Hartzaileak \\
\hline Lan sustapenerako politikak & Sustapen programak & $\begin{array}{l}\text { Auto enplegua eta } \\
\text { enpresen sorkuntza, } \\
\text { lan poltsak, Inemeko } \\
\text { dirulaguntzak, etab. }\end{array}$ & \multirow{3}{*}{$\begin{array}{l}\text { Izaera ekintzailea, lan } \\
\text { autonomoa, enpresen } \\
\text { sortzea sustatu, etab.; } \\
\text { lana eta kualifikazioa } \\
\text { hobetu }\end{array}$} & \multirow{3}{*}{$\begin{array}{l}\text { Nagusiki, } \\
\text { langabetuak eta } \\
\text { bazterketa arriskuan } \\
\text { dauden kolektiboak }\end{array}$} \\
\hline Prestakuntzarako politikak & Prestakuntza programak & $\begin{array}{l}\text { Lanerako prestakuntza } \\
\text { profesionala, ofizio etxeak, } \\
\text { lan tailerrak, prestakuntza } \\
\text { eta lan gizarteratze } \\
\text { tailerrak, etab. }\end{array}$ & & \\
\hline $\begin{array}{l}\text { Orientazio eta enplegu } \\
\text { zerbitzu politikak }\end{array}$ & Orientazio programak & $\begin{array}{l}\text { Enplegurako eta } \\
\text { autoenplegurako orientazio } \\
\text { ekintzak eta zerbitzuak }\end{array}$ & & \\
\hline
\end{tabular}

Iturria: Calvo eta Lerma (2009), egileak itzulita.

tzen direnak. Oinarrizko printzipio dira aktibazioa, indibidualizazioa, enpleguari lehentasuna ematea eta kontratuko printzipioa (Moreira [2008], EguíaCareaga Fundazioaren [2012a] liburuan aipaturik).

Gizarteratzeko politika aktiboen ezaugarriak: izaera konpontzailea, erabakigarria, ekintza zehatzak, integratzailea eta esperimentala. Ezaugarri horiek eta jarraitzen dituen helburuak aintzat hartuta, 5. koadroako politika eta programak garatu dira.

Gizarteratze politikei ondorengo hiru kritika nagusi hauek egin zaizkie (Calvo eta Lerma, 2009):

- Kritika formala: azken urteetan aurrera eraman diren politika aktiboak ez dira egokitu gizartean eman diren aldaketa sozial eta ekonomikoetara. Hau da, gizarteak aldaketak jasan dituen bitartean, gizarteratzeko politika aktiboak egonkor jarraitu dute. Malgutasun falta honek egungo politikak eta egungo gizartearen beharrak bat ez etortzea ekarri du.

- Eraginkortasunaren inguruko kritika: orokorrean, eredu finalista izaten jarraitzen du. Ebaluaketarako datu kuantitatiboak erabiltzen ditu, batez ere, gastuaren justifikazioan oinarrituta, eta ez dira neurtzen datu kualitatiboak edo zentzu honetan lortu diren lorpenak. Ebaluaketarako adierazle gutxi neurtzen dira eta gainera, mekanismo gutxi aurreikusten dira honetarako. Epe motzerako ikuspegiarekin neurtzen dira lorpenak.

- Kritika instituzionala: enplegu arloan eskumena duten administrazio ezberdinen arteko koordinazio eza. Askotan, ez dira helburuak mantentzen arau mailan eta exekuzio mailan.

EAEko kasu zehatzera jotzen badugu, gizarteratze aktiborako politikak batez ere enpleguan oinarritu direla esan daiteke. Bazterkeriaren atzean arrazoi ezberdinak eta ugariak daudela onartzen den arren, honi aurre egiteko neurriak batez ere lan arloari zuzenduta garatu dira; laneratzea lortuz gero bazterkeria eta pobreziarekin amaituko dela pentsatuz. Horrela, epe baterako lan kontratazio, praktika kontratu eta antzekoak sustatu dira, baina honek ez ditu egiturazko arazoak konpondu. Neurri hauekin pertsona denboraldi baterako lan merkatuan txertatzea lortzen zen, une batez bere gizarteratzea hobetuz, baina kontratuaren epea amaitu ostean, erabiltzaile asko eta asko beren hasierako egoerara itzultzen ziren.

Eredu honen beste akatsetako bat izan da kolektiboaren perfilera ez egokitzea. Dispositibo honen onuradun diren pertsonen perfila aztertzen badugu, gurasobakarreko familiekin, sare sozial apaleko pertsonekin, ezintasun bat duten pertsonekin eta beste batzuekin topatzen gara, eta ondorioz, lan merkatuko ezaugarrietara egokitzeko zailtasunak dituzten pertsonak dira. Gizarteratzeko politikek askotan ez dute kontuan hartu pertsona horien egoera pertsonala, eta ondorioz, askotan zailtasunak edo ezintasunak eman dira programak eta egoera pertsonalak uztartu ahal izateko. Frustrazioaz gain, motibazio eza eta pasibitatea eragiten ditu horrek.

Soilik dirulaguntzak eta lana elkartzean, horrelako egitarau eta tresnen atzean beste sistema batzuen bateratzeak ere kontuan hartu behar direla ahaztu da. Kasu batzuetan lan arloa zaintza familiarrarekin lotu behar da, beste batzuetan, lan arloa eta osasun arloa elkartu behar dira, eta horrek babes sistema ezberdinen arteko koordinazioa eskatzen du.

Hutsuneak aipatzerakoan, lan pizgarriak ere kontuan hartu behar dira. Aktibazioa lortu ahal izateko, erakargarria izan behar du, eta eskubide bat dela aipatzeaz gain, honekin lortzen diren onurak landu behar dira. Soilik lanarekin lotzen bada, arlo ekonomikoaren inguruko konparaketa egiten da batez ere, eta ondorioz, lan eginez lortzen den eta prestazioarekin lortzen den etekin ekonomikoa alderatzen dira. Kasu askotan, lan eginez etekin ekonomiko gehiago lortzen dela ikusten da, baina prestazioaren onuraduna ez izatean, beste hobari batzuk galtzen dira (bekak, hainbat gastutarako laguntza edo onurak, eta ondorioz, ez da errentagarria lan egitea. Egia da laneko diru sarrerak dituztenei lan pizgarriak aplikatzen zaizkiela, eta horrela, lan eginez diru sarrera handiagoak lortzeko aukera dagoela, baina baremoen mugan aurkitzen diren pertsonek hainbat kasutan onura gehiago galtzen dituzte lan merkatuan parte hartuta. Ondorioz, zalantzan jarri izan da kasu 
batzuetan zenbateraino den onuraduna lan merkatuan partehartzea edo dirulaguntzen onuraduna izatea.

Beraz, esan daiteke arazoa errotik konpondu beharrean horren eragina gutxitzea eta kontrolatzea izan dela aktibazio politiken helburua.

\subsection{Lanbideren desantolaketa}

Dispositibo honek izan duen beste aldaketa bat izan da kudeaketaren inguruko eskumen aldaketa. 2010eko urte amaieran, enpleguko politika aktiboen eskumen transferentzia burutu zen, eta 2011ko urtarriletik aurrera, Eusko Jaurlaritza (Lanbideren bitartez) enpleguko politikak kudeatzen hasi zen. Politika aktibo hauen barruan, gizarteratze politikez gain, dirulaguntzen kudeaketa ere sartzen zen.

Eskumen aldaketa hau etorriko zela aurreikusirik, dirulaguntzak enpleguko politika aktiboen barnean kokatu nahi zituzten, gizarteratzeko politika aktiboen parte direla ulertzen baita, eta horregatik, euren kudeaketa Lanbideren barnean ulertzen zen. Hau egoki kudeatu ahal izateko eta etorriko zen aldaketarako prest egoteko, esperientzia pilotuak ipini zituzten martxan 2010eko ekainean ondorengo zortzi herritan: bi Araban (Agurain eta Amurrio), hiru Gipuzkoan (Elgoibar, Lasarte eta Irun) eta hiru Bizkaian (Basauri, Erandio eta Portugalete) eta, printzipioz, urte amaiera arte egongo zen martxan.

Aldaketa horren bitartez, lan aktibazioari eman nahi zitzaion indarra. Lanbideren bitartez, prestazioaren onuradunei lanerako aktibatuko zitzaien euren ezaugarrietara egokitzen zen ikastaro eta heziketaren bidez. Horrela, Lanbiden bertan izenpetu zuten lan aktibaziorako kontratua.

Honez gain, kudeaketaren bizkortasuna ere lortuko zen. Prestazioaren kudeaketan hiru administrazio ezberdinek parte hartu beharrean, prozesu guztia administrazio bakarraren esku geratuko zen, eta honek eragin zuzena izango zuen prestazioaren ebazpena azkartzean.

Azaldu den moduan, aldaketa horren arrazoi nagusia enplegu politiken ikuspegi berrian zegoen baina baita ere aurreko funtzionamenduaren akatsak edo ahuleziak konpontzeko nahian. Hurrengo kritikak egiten zitzaizkion aurreko sistemari (dirulaguntzen kudeaketa gizarte zerbitzuetatik egiteari):

1. Prestazio ekonomikoari ematen zaio garrantzia eta ez pertsonaren lan aktibazioari.

2. Asistentzia sistema bat da.

3. Pertsonak dirulaguntzen mendeko bihurtzen ditu.

4. Prestazioaren kudeaketa hiru administrazioen esku egotean, prozesuak gehiegi irauten du.

5. Gizarte langileek lan administratiboak egin dituzte gizarte langilearen betekizun propioen ordez.

6. Dirulaguntzek betebehar batzuk dituzte eta betebehar hauen jarraipen eskasa egin da.

7. Eskuartzeko eta sistematizatzeko eredu estandar baten falta. Foru Aldundi eta udal bakoitzak bere sistematizazio ereduekin funtzionatu du.

Esperientzia pilotua martxan jarri eta sei hilabetetara, hau da, 2010eko abenduan, programa horren inguruko ebaluaketa bat egin zen Errenta Aktiboaren Plan Pilotuaren egoeraren informazioari buruzko txostenean argitaratu zena. Honen helburua, alderdi positiboak eta negatiboak ebaluatu eta aldaketak egin ahal izatea zen, programa udalerri guztietara zabaldu aurretik atzemandako hutsegiteak konpondu ahal izateko. Ebaluaketa horretatik ateratako datuak AMIA analisi baten bidez irudikatu zituzten (6. koadroa).

Ebaluaketa horrek 2011. urtean udalerri guztietara zabalduko zen sisteman aurkitu zitezkeen hutsune eta akatsak konpontzeko balio behar zuen. Hala ere, aipatzekoa da 2011ko maiatzean egin zen amaierako ebaluaketan aurrekoan aipatzen ziren antzeko

6. koadroa. Lanbideko esperientzia pilotuaren ebaluaketa

\begin{tabular}{|c|c|}
\hline Ahuldadeak & Mehatxuak \\
\hline $\begin{array}{l}\text { - Arreta txandak hobetzeko beharra. } \\
\text { - Aurreko sistemarekin konparatzen da. } \\
\text { - Lan metodologia eta erabiltzen diren aplikazioak ez daude nahi- } \\
\text { taezkotasun printzipiora egokituak. } \\
\text { - Gehiegizko barneko lan kargak derrigorrez eskatzen ditu pertsonal } \\
\text { arloko ez diren tresnak. } \\
\text { - Tresna osagarrien falta: garraiorako bekak, haurtzaindegiak, etab. } \\
\text { - Funtzio hori egoki bete ahal izateko bulegoak ez daude egokituta } \\
\text { (espazio fisikoa). }\end{array}$ & $\begin{array}{l}\text { - Lankidetza arazoak bulego, udal eta diputazioen artean. } \\
\text { - Izapidetze fasean ematen ziren kolapsoak prozesatze fasera igaro. } \\
\text { - Udaletik datozen erabiltzaileak aldaketa ez onartzean sortzen } \\
\text { dituzten arazoak. } \\
\text { - Laguntzak eteteko garaiak protokolo objektiborik ez izatea. } \\
\text { - Arlo politikotik babes gehiago eskatzea. }\end{array}$ \\
\hline Indar guneak & Aukerak \\
\hline $\begin{array}{l}\text { - Izapidetzan eta aktibazioan egoki kualifikatua dagoen pertsonala. } \\
\text { - Izapidetzeko itxaron denbora murriztea } \\
\text { - Aktibazio lana hasteko aukera. } \\
\text { - Arreta espezializatua, pertsonalizatua eta pertsonara egokitua } \\
\text { - euren lan gizarteratzea lortzeko helburuarekin. } \\
\text { - Pertsonen lan aktibatzerako aukera errealak, tresna zehatzekin. }\end{array}$ & $\begin{array}{l}\text { - Espedientearen kudeaketan pertsonaren autonomia sustatzea. } \\
\text { - Pertsonen lan gizarteratzean partehartze aktibo bat sustatzea. } \\
\text { - Lan eta gizarteratze neurrien onarpen sozial hobea lortzea. } \\
\text { - Arreta eta erabakitze zerbitzu juridiko tekniko bat sortzea, irizpi- } \\
\text { deak bateratuz eta sistemari legitimitate gehiago emanez. } \\
\text { - Potentzialki enplegura sartzeko ahalmena duten pertsonak siste- } \\
\text { man geratzea ekiditea. }\end{array}$ \\
\hline
\end{tabular}


gabezia eta hutsune berberak aipatzen zirela. Hasieran, eta politikoki horrela adierazita, sistemaren eskumen aldaketa 2011. urtean zehar gertatu behar zen, eta data ezberdinez hitz egin arren, eskumen aldaketa, azkenean, $2011 \mathrm{ko}$ abenduaren 13an egin zen. Data zehazteko garaian gorabehera handiak egon ziren, eta gutxiena espero zen unean egin zen. Urte osoan epe ezberdinak zehazten ibili ostean, azkenean 2012ko urtarrilaren 1ean izango zela erabaki zen eta, hori gauzatu ahal izateko, 2011ko abenduaren 31ean hori onartzen zuen dekretua argitaratuko zen. Hala ere, gauzak ez ziren horrela izan. 2011ko abenduaren 12an, eskumen aldaketa onartzen zuen dekretua argitaratu zen, eta aipatzen zuen hurrengo egunean sartuko zela indarrean. Dekretu horren argitalpena, ordu arte arlo horretan eskumena edo kudeaketa zuten administrazio ezberdinei abisatu gabe egin zen (udalak eta foru aldundiak). Ondorioz, administrazio hauen haserre eta kexuak etorri ziren.

Eskumen aldaketa horren funtsean dauden helburuak eta lortu nahi diren emaitzak egokiak diren arren, aldaketak gauzatu ahal izateko aurrera eramaten ari den modua eta bidea ez dira egokiak izan. 2010ean, esperientzia pilotuak martxan ipini ziren esperientzia hauetatik ikasi ahal izateko, eta 2011 urte guztia erabiltzeko aukera egon zen eskumen aldaketa egoki bat egin ahal izateko (bai parte hartzen zuten administrazio ezberdinen artean bai herritarrei begira ere), baina emaitzak ez ditu aurreko ildoak islatzen.

Hasieratik, gauzak nahiko gaizki antolatu ziren, eta eskumen aldaketa egin zela urtebete pasa ostean, nire esperientzia pertsonaletik hurrengo emaitzak edo datuak eman ditzaket:

- Esperientzia pilotuetatik lortutako datu, ebaluaketa edo emaitzak ez dira argitaratu edo ez da egin horien inguruko zabalkunderik.

- Bergarako kasuari dagokionez, eskumen aldaketa egoki egiteko 2011ko abenduaren 13an udaletxetik hasi gabe genituen eskaerak Lanbidera bideratu behar genituen; gure kasuan 11 espediente (DBE eta ELO). Espediente guztiak prestatu ostean, 2012ko urtarrilaren 2an Lanbidera bideratu ziren (Gasteizko bulego orokorrera). Bertan, 2012ko urtarrilaren 5ean jaso zituzten eta une horretatik aurrera, berauena zen espedientearen kudeaketa eta ardura. Espediente horien lehenengo ebazpena otsailean iritsi zen, baina azkena, aldiz, irailean. Hilabete horietan guztietan, erabiltzaileak Lanbideko bulegoetan euren espedienteen inguruan galdetzen ibili ziren, eta inork ez zieten erantzuten. Kasu batzuetan, maiatza inguruan, esan zieten espedienteak galduta egon zitezkeela, eta badaezpada eskaera berriz egiteko. Ondorioz, hilabete horiek galdutzat eman zizkieten. Udalera ere deitu ziguten dokumentazioaren kopiak izanez gero, berriz bidaltzeko esanez, txostenak egiteko langileriaren beharra adieraziz, etab. Ondorioz, espedientearen ebazpenak azkartu beharrean atzeratu egin ziren eta kasu batzuetan hilabete asko.
- Atzerapenen ondorioz, kasurik larrienean, ia $8.000 €$ jaso zuten halako batean. Lehen irakurketan gauza positibo bezala ikusi daiteke baina diru hori jaso bitartean inolako diru sarrerarik gabe egon ziren. Beste alde batetik, erabiltzaile batzuen perfila ikusirik, arriskutsua izan daiteke bat batean horrenbeste diru jasotzea (kasuak ezagutzen ditugu horrelako atzerapenak jaso eta gero desagertu egin diren pertsonenak). $8.000 € k o$ kopurua ez da ohikoena, baina bai 3.000-4.000€ horrek duen ezegonkortasunarekin.

- Aurrez aipatutako sistema berriaren funtzionamendua eta lankidetza moduak azaltzeko bilera bat antolatu behar zuten udal guztiekin, eta lehenengo koordinazio bilera 2012ko urriaren 2 an izan zen. Bertan, Lanbidetik ezarri nahi den lankidetza protokoloa azaldu zuten bestelako azalpenik eman gabe. Ordutik ez da harreman edo deialdi gehiago egon.

- Planteatu den sistemaren arabera, lehen harremana eta orientazioa Lanbidetik egingo da, eta lan aktibazioaz gain, bestelako arloak landu behar direla ebaluatuz gero, gizarte zerbitzuetara bideratuko dituzte erabiltzaileak. Alde batetik, orientazioa eta balorazioak egingo dituen profesionalaren heziketa lizentziatura izango da, bestelako argibiderik eman gabe. Beste aldetik, 12 hilabete igaro dira orientazio eta deribazio prozesuak martxan hasi behar zutenetik, eta oraingoz, ez zaigu inolako kasu berririk iritsi.

- Lan aktibaziorako horren beharrezko diren hitzarmenak behin eta berriz aipatu dituzte, baina lehen hitzarmenak orain hasi dira sinatzen, ia urte bete pasa ostean. Bitarte honetan, erabiltzaileek ez dute izan inolako orientaziorik, erreferentziazko profesionalik, inolako betebeharrik, etab.

- Bergarako udalaren kasuan, dirulaguntzen onuradun guztiekin (pentsionistak izan ezik) lan eta gizarteratze hitzarmenak sinatzen genituen, erabiltzailearekin adostu ostean landu nahi ziren helburuak. Gure kasuan, eskumen aldaketa egitean Lanbidera, hitzarmen guztien inguruko laburpen bat bidali genuen erabiltzaileekin lantzen ari ginenaren inguruko informazioa izan zezaten. Ez dira harremanetan jarri, laburpen hauen inguruan izan zitzaketen galderen azalpenak eskatzeko. Beste udalerri batzuk erabaki zuten laburpen hori ez bidaltzea. Udal horiekin ere ez dira harremanetan jarri jakiteko ordu arte zer landu zen.

- Hainbat erabiltzailerekin dirulaguntzez gain beste arlo batzuk ere lantzen genituen gizarte zerbitzuetatik. Pertsona hauekin lanean dihardugu, eta kasu batzuetan, Lanbidetik informazioa behar dugu edo galdera batzuk erantzutea, eskuartzean aurrera jarraitu ahal izateko. Batzuetan, larrialdizko kontsultak dira, erantzunaren arabera eskuartzean zuzeneko eragina baitu. Kasu horietan galdera egin eta hilabetera jaso dugu erantzuna.

- Kontuan izanik, orain arte zerbitzu egoki bat eskaini ahal izateko eta prestazioaren kudeaketa apropos bat egin ahal izateko zenbat profesio- 
nal ibili diren arlo honetan lanean, Lanbidek egin dituen kontratazio berriak ez dira nahikoak eskaera bolumenari egoki erantzun ahal izateko.

Orain arte azaldu ditudan gabezia eta hutsuneak profesional modura bizitakoak dira, baina maila orokorrean ere, erabiltzaileek adierazitako gabeziak ildo horretan doaz. Erabiltzaile eta eragile sozialek adierazten dituzten kexa nagusiak hurrengoak dira:

- Ez dira sortu kolektibo zehatz batzuek gizarteratze planak jarraitzeko dituzten mugak kontuan hartuz landutako hitzarmenak eratzeko irizpideak.

- Ez dira ebazpen epeak errespetatzen.

- Egonezin orokorra, pertsonak hilabete dezente egoten direlako ezer kobratu gabe eta ondorioz, ezin dituzte ordaindu dituzten gastuak (batez ere etxebizitzari lotuak).

- Desinformazioa:

- Ez dago kontsultak egiteko biderik.

- Informazioa lortzeko dauden bideetan itxaron zerrenda luzea dago.

- Bulego batzuetan informazio okerra edo desegokia ematen da.

- Ez dira iristen laguntzen onarpen, ez onarpen edo berrikuntzen jakinarazpenak.

- Ez dago zerbitzu teknikorik espedientearen egoeraren inguruko kontsultak egiteko edo zalantza teknikoak ebazteko.

- Iradokizun eta kexen orriak eskatzean ez dira ematen.

- Lanbideko bulegoetan dokumentazioa aurkeztu eta tekniko batek baloratzeko zailtasunak ipintzen dituzte.

Ildo honetan, jendeak duen ezinegonaren eta kexen isla gisara, Arartekoak kexa ugari jaso ditu. 2012ko txostenaren arabera (Ararteko, 2013), gizarte gaien inguruko kexak \% 320 igo dira. Guztira, 1.010 kexa jaso dituzte eta horietatik 875 , hau da, \% 9oa, Lanbideren kudeaketaren ingurukoak izan dira.

\subsection{Etorkinen penalizazioa}

Penalizazioak aztertzen hasi aurretik, atzerritarrak Euskadira nola iristen diren aztertuko dugu, zein egoeretan topa daitezkeen ikusteko:

- Atzerritar erregimen orokorra: jatorrian egindako lan eskaintza batekin. Estaldura zaila duten lanen katalogo bat dago, eta bertan agertzen den lan eskaintza batekin etortzen da pertsona. Gaur egun oso zaila da.

- Erregimen orokorra, egoera zehatz batekin: atzerritar baten seme alaba izatea, espainiar nazionalitatea duen pertsona baten seme alaba edo biloba izatea, etab. Lan eskaintza bat behar dute, baina lan eskaintza hau ez dago aurrez aipatu den katalogora mugatuta.

- Familia berriz elkartzea.
- Espainiara sartzeko baimena behar ez den herrialde batetik etortzea, batez ere, Ertamerikako herrialdeak. Turista gisa, modu legalean sartzen dira, eta 90 egun igaro ondoren, modu irregularrean geratzen dira bertan. Errotze sozialaren bidez euren egoera arautu behar dute.

- Espainiara sartzeko baimena eskatzen den herrialdeetatik datozen pertsonak. Modu ilegalean eta klandestinoan sartzen dira. Hasieratik modu irregularrean aurkitzen dira.

- Beste autonomia erkidego batean bizi ziren pertsonak, modu erregular edo irregularrean, eta Euskal Autonomia Erkidegora etortzen diren pertsonak. Mugimenduak Estatu barruan ematen dira.

EAEn sartzeko edo bertara iristeko oraintxe aipatutako aukerak egon arren, normalean, errotze txostenaren bidez lortzen dira lehen lan eta egoitza baimenak. Horretarako, hiru urteko errolda eta bizikidetza jarraia ziurtatu behar dira eta urtebeteko lan kontratu bat aurkeztu behar da. Bitarte horretan, pertsonak nolabait biziraun behar du.

Baldintza hauetatik abiatu eta lan eta egoitza baimena lortu arte, egoera horretan aurkitzen diren pertsonak dirulaguntzetatik edo azpienplegutik bizi direla ondorioztatu dezakegu.

4/2011 Legeak, 18/2008 Legean aldaketa batzuk ezartzen ditu, eta aztertzen ari garen kasuan, hurrengo aldaketak ditu:

- Dirulaguntzak eskatu ahal izateko, baldintza hauek bete behar dira:

- Eskabidea aurkezteko unean, Euskal Autonomia Erkidegoko edozein udalerritan erroldatuta egotea eta benetan bertan bizitzea, eta eskabidea egin baino urtebete lehenagotik, gutxienez, Euskal Autonomia Erkidegoko edozein udalerritan erroldatuta egon izana eta benetan bertan bizitzea.

- Aurretiazko gutxieneko epea betetzen bada, baina hiru urtean erroldatuta egotera iristen ez bada, gutxienez bost urteko laneko jarduera ordaindua egiaztatu beharko da, bizitza laboralaren agiri bidez, pentsio publiko bat jaso edo etxean tratu txarren biktima izan diren pertsonen kasuak salbu.

- Gutxieneko epe hori bete ezean, eskatzaileak aurreko hamar urteren barruan bost urtez jarraian Euskal Autonomia Erkidegoko edozein udalerritan erroldatua eta bertan benetako egoitza beharko du izan.

- Aldaketa hauek ikusirik, modu irregularrean sartzen diren pertsonak lehenengo hiru urteetan sistema guztietatik kanpo geratzen dira. Alde batetik, lan baimena ez dutenez, ezin dute lan merkatuan sartu. Beste aldetik, Lanbideren heziketa askotarako lan eta egoitza baimena eskatzen dituzte, eta ondorioz sistema honetatik kanpo geratzen dira. Azkenik, dirulaguntzak 
eskatu ahal izateko hiru urteko errolda eskatzen denez, sistema honetatik ere kanpo geratzen dira. Beraz, errealitatea hurrengoa da:

- Modu irregularrean sartzen dira pertsonak. Badakigu hainbat pertsona modu honetan daudela, baina ez da neurririk hartzen egoera hori ekidin ahal izateko. Hala ere, sartzen uzten zaien arren, ez zaie lan eta heziketa aukera ematen lan eta egoitza baimena izan arte. Beraz, prestazio ekonomikoetatik edo azpienplegutik bizi direla onartzen da. Azken aldaketa honekin, prestazio ekonomikoetatik kanpo uzten dira hiru urteko errolda lortu arte. Beraz, azpienplegua da bizirauteko duten modu bakarra.

Beste kasu batzuetan, modu erregularrean daudenei ere eragin diezaieke. Lan eta egoitza baimenak berrizteko garaian, lan kontratua mantentzea edo lan kontratu berri bat izatea eskatzen zaie, baina salbuespen bat ere badago, hau da, prestazio ekonomiko bat jasotzen jardutea bere gizarteratze sozial eta laborala lortu ahal izateko. Kasu horietan, lan kontraturik gabe geratuz gero, eta hiru urteko errolda bete ezean, egoera erregularrean egotetik egoera irregularrean egotera pasa daitezke, horrek dakarren eskubide galera guztiarekin.

Legean aldaketa emateko gobernuak emandako arrazoiak hurrengoak dira:

- Diru sarrerak bermatzeko errenta lanarekin lotu behar da. Erabiltzaileak ezin dira sisteman kroniko bihurtu prestazioaren erabiltzaile moduan, ezin da aukeratu lan egin edo prestazioaren kontura bizitzea, ezin dira lan eskaintzak ukatu, etab.

- Iruzurraren aurkako borroka. Hau ekidin ahal izateko administrazio bakarrak eman behar du kudeaketa.

- Dena ezin da ordaindu, eta murrizketak egin behar dira. Gaur egungo egoera ez da aurreko urteetan bizi izandakoa, eta murrizketak egin behar dira sistema jasangarria izan dadin.

Gobernutik emandako arrazoi horiek errealak izan daitezkeen edo ez eztabaidatzen hasi gabe, ez dute justifikatzen legean eman diren hainbat aldaketa, beraz, atzetik egon daitezkeen interesak aztertu beharko dira.

Orain arte aipatutako egoerak prestazioen sistemara sartu ahal izateko mugen ingurukoak izan dira, baina gobernutik hartzen ari diren neurriak beste kasu batzuetan ere atzerritarrak sistematik kanpo uzten ditu.

Behin eta berriz aipatzen ari gara prestazio ekonomikoaren oinarrian gizarteratze aktiboaren filosofia dagoela. Prestazioak, eskubide eta betebehar batzuk ematen ditu, eta horien artean aurkitzen da gizarteratze aktiborako eskubide eta betebeharra. Helburu hau lortu ahal izateko, tresna ezberdinak jartzen dira martxan, hala nola, lan bilaketa, heziketa, etab.

Prestakuntzari dagokionez, ateak itxi zaizkie lan baimena ez duten pertsonei. Ondorioz, aurretik prestazio ekonomikoaren onuraduna zen kolektibo bat heziketatik at geratu da. Hori dela eta, euren eskubide eta betebehar bat burutzeko zailtasunekin aurkitzen da; euren gizarteratzea lortu ahal izateko prestakuntzatik kanpo geratzen baita, eta, aldi berean, administrazioak (printzipioz) euren eskubide bat ukatzen die.

\subsection{Zaintza mekanismoen sendotzea}

Orain arte azaldu den moduan, dispositibo honen oinarrian gizarteratze aktiborako eskubide eta betebeharraren filosofia aurkitzen da, eta horretarako tresna eta baliabide ezberdinak ipini ditu sistemak. Ibilbide honen ahulezia eta gabezia ezberdinak azaldu ditugu aurrez, eta azkeneko ahulezia moduan, sistemaren objektibitatea eta zuzentasuna zaindu nahian, iruzurraren inguruan eratu den mekanismoa landuko dut.

Diru publikoaz hornitzen den dispositibo batez ari garenez, bidezko banaketa bat egiten dela bermatu nahi da; alde batetik, erabilera egokia egiteko, eta beste aldetik, sentsazioa ez izateko gizartearen zati batek bestea mantentzen duela. Banaketa hori egoki egiten dela ziurtatzeko, kontrol edo berme ezberdinak erabiltzen dira; administrazio ezberdinen arteko koordinazioa datuen inguruan, erabiltzailearen betebeharra aldaketen berri emateko, jarraipenak, etab.

Hala ere, azken aldian (batez ere krisiaren eraginaren ostetik) iruzurrak ugaritu egin izanaren mamua zabaldu da; bai komunikabideetan adierazten denarengatik bai gobernutik eman diren berriengatik bai gizartean dagoen kezkarengatik. Kontrol falta handia egon dela leporatu zaie gizarte zerbitzuei, erabiltzaileei betebehar propioak ez zaizkiela exijitu, onuradun asko iruzurretan ibili direla, eta dispositiboaren kudeaketaren eskumen aldaketarako arrazoietako bat ere hori izan omen da, hau da, iruzurrarekin amaitzea.

Oinarrietako helburuetara jotzen badugu, jarraipenen atzean gizarteratzea lortu ahal izateko pertsonaren aktibazioa aurkitzen da, eta jarraipen horietan onuradunak profesionalaren laguntza jasoko du ibilbide hori landu eta garatu ahal izateko. Hala ere, iruzurraren inguruabar honetan jarraipen hauek kontrol gisa planteatzen direla dirudi. Jarraipen horietan pertsona aktibatu beharrean, eta bide horretan landuko diren eremuak adostu beharrean, bere egoerak berdin jarraitzen du, egoera kaltebera batean jarraitzen du, dena ongi bete ote duen, eta kontu ematera joan behar duela dirudi. Ez da bilatzen banakotasun eta gizarteratze printzipioak jarraituz zerbitzu integral eta indibiduala eskaintzea, baizik eta banakako kontrol eta jarraipen bat egitea.

Kontrolaren ideia honi jarraituz, alde batetik erabiltzaileen kontrola bilatzen dela azaldu da, baina beste aldetik, iruzurra zer den eta zein neurri hartu behar diren irizpideak ez dira markatu. Kezka handia eta konpontzeko nahi handia erakutsi arren, ez dira beharrezko adierazleak markatu, denek garbi izan 
dezaten zer den iruzurra eta zein ondorio dituen. Ondorioz, batentzat iruzurra dena agian bestearentzat ez da. Kasu batzuetan neurri zehatz batzuk hartzen dira eta beste batzuetan ez. Irizpide falta honek parean tokatzen den profesionalaren esku uzten du iruzurra den edo ez erabakitzea, eta neurriren bat hartu behar den edo ez ikustea.

Beraz, alde batetik, bidezkotasun eta objektibitate printzipioak oinarri hartuta funtzionatu nahi dela esaten da, baina beste aldetik, objektibitate eta bidezkotasun printzipio horiek bermatzeko beharrezkoak diren irizpideak landu eta garatu gabe utzi dira.

\section{Oinarrizko errenta unibertsal batera iristeko aukera}

Orain arte, indarrean dagoen sistemaren azterketa bat egin dugu, maila orokorretik hasi eta maila zehatzera iritsi arte, eta bidean, dispositiboak dituen gabezia eta hutsuneak azaldu ditugu. Hurrengo atalean, dispositibo honen alternatiba bat izan daitekeen aukera aztertuko dugu. Atal honen marko teorikoa lantzeko Gorka Moreno Márquezen Herritartasuna berdefinitzen: Oinarrizko Errenta (2006) liburua erabili dut oinarri eta erreferentzia moduan.

Lehenik eta behin, oinarrizko errenta unibertsala definituko da. Hurrengo definizioak topa ditzakegu:

Oinarrizko Errenta, gizabanako guztiei baldintzarik gabe ordaintzen zaien errenta da, dituzten baliabideak eta lanean ari diren edo ez kontuan izan gabe (Basic Income European Network).

Oinarrizko Errenta, Estatuak eskubide osoko orori edo gizarte horretan bizi denari ematen dion diru sarrera da, hiritartasun eskubide bezala; ordainduriko lanik egitea baldintza izan gabe eta aberats edo txiro den kontuan hartu gabe. Beste era batera esanda, ez da kontuan hartuko beste diru iturririk ote duen edo norekin bizi den (Oinarrizko Errenta Sarea).

Definizio honi jarraituz, ondorengo kontzeptu hauek argitu behar dira (Moreno Márquez, 2008):

- Estatuak: honekin erakunde publikoek bultzatutako ekimena izan behar duela azaldu nahi da, zehaztu gabe zein erakundek izan behar duen.

- Eskubide osoko orori edo gizarte horretan bizi denari emandako diru sarrera: proposamenaren izaera indibidual eta unibertsala azpimarratu nahi da.

- Horrek ez badu ordaindutako lanik egin nahi: enpleguaren mugak gainditu eta beste enplegu mota batzuk ere kontuan hartu nahi dira (etxeko lanak, boluntario lanak, etab.).

- Kontuan hartu gabe aberats edo txiro den: eskubide unibertsalaren ildotik doa.
- Ez da kontuan hartuko beste diru iturririk duen edo norekin bizi den: izaera indibiduala defenditzen da.

Jarraian, Oinarrizko errentaren arlo ezberdinak landuko dira.

\subsection{Oinarrizko Errenta Unibertsalaren aurrekariak ${ }^{3}$}

Gaur egun, Oinarrizko Errenta gisa ezagutzen dugun kontzeptura iritsi aurretik, diziplina ezberdinetako autore ezberdinek gai honen inguruko proposamen, eztabaida edo ideiak landu zituzten, hala nola, filosofo, politikari, ekonomista edo humanistek, bakoitzak bere ekarpena eginez. Hala ere, Oinarrizko Errentaren benetako garapena ondorengo testuinguru honetan eman zen:

- Alde batetik, Bigarren Mundu Gerra ostean hasitako eredu kapitalista 1973an gainbehera hasi zen, eta ondorioz, Ongizate Estatuaren gainbehera ere iragarri zen.

- Ekialdeko Estatuen blokea indarra galtzen hasi zen. Aurrean oposiziorik ez izatean, eredu kapitalista berria indartzen hasi zen.

Testuinguru sozial, politiko eta ekonomiko horrek, ordurarte gutxi batzuek landutako eta eztabaidatuko ideiak garatzeko aukera ematen zuen. Garapenaren bidean, lan handia egin zuten hurrengo lau autoreek:

- Juliet Rhys-Williams (1943) eta Eric Fromm (1955): gaur egungo sailkapenari jarraituz, eredu ahul gisa bezala ezagutzen den proposamena landu zuten. Rhys-Williamsek egiten duen proposamenak izaera unibertsal eta indibiduala du baina lanaren kontzeptuari oso baldintzatuta dago. "Zerbait lortu ahal izateko lehenengo irabazi egin behar da" pentsamenduaren kutsu handia du. Frommen proposamenak ere izaera unibertsal eta indibiduala zuen, baina ezaugarri pertsonaletara baldintzatu behar zen.

- Robert Van der Veen eta Philippe Van Parijs: oinarrizko errentaren hiru ezaugarri nagusiak batzen dituen proposamena egin zuten, hau da, izaera unibertsala, indibiduala eta baldintzarik gabea, eta proposamenari eman zioten egitura ekonomiko, sozial, politiko eta filosofikoa. Oinarrizko errenta unibertsala pertsonaren askatasunarekin lotzen dute. Ez dago askatasun errealik garatzeko tresnarik, eta tresna edo neurri horiek izan ezean, baliabideen birbanaketaren inguruko erabaki politiko eta sozialak eskatzen dituzte (Van Parijs eta Vanderborght, 2006).

1970 eta 80. hamarkada hasieran autore ezberdinen ekarpen batzuk egon ziren, baina oinarrizko erren-

3 Daniel Raventós egilearen La renta básica como derecho de existencia social (2008) testuan oinarrituta dago atal hau, eta testu hori 2007an argitaratu zuen Basic Income: the Material Conditions of Freedom (2007) liburuko 1. eta 9. ataletan oinarritua dago batez ere. 
taren historian urte garrantzitsua da 1986. urtea. Bi urte lehenago, Charles Fourier Taldeak (ikertzaile eta sindikalista taldea) Lovaine Unibertsitateko kideak L'allocation universelle (Oinarrizko Errenta) lana aurkeztu zuen. 1986an, Belgikan emandako sari garrantzitsu bati esker, aurrez aipatutako Unibertsitatean Oinarrizko Errentaren inguruko kongresu bat antolatu zen. Kongresu horrek herrialde ezberdinetako ikertzaileak bildu zituen, eta bertan sortu zen Basic Income European Network (BIEN) sortzeko ideia. Ordutik, hamar kongresu antolatu ditu BIENek eta inork ez du zalantzan jartzen bere garrantzia.

Aipatzekoa da 2004ean, Bartzelonan burutu zen kongresuan, eman zen aurrerapen garrantzitsua. Ordurarte Basic Income European Network bezala ezagutukoa, Basic Income Earth Network izatera pasa zen, Europaz haratago mugak gaindituz. Horrela, Europa mailako sare bat izatetik mundu mailako sare bat izatera igaro zen, Oinarrizko Errentaren inguruko eztabaida mundu osora zabalduz. Oinarrizko Errenta Sarearen helburuak hurrengoak dira:

- Oinarrizko Errentaren inguruko ikerketa zientifikoa sustatu, bai teorikoa bai enpirikoa.

- Arlo honetan adituak diren pertsonen prestakuntza eta hobekuntzan lagundu.

- Gai honen inguruan interesa duten pertsona eta erakundeen arteko informazio trukaketa eta komunikazioa sustatu, maila nazional eta nazioartean.

- Berak bakarrik edo beste erakunde batzuekin lankidetzan kongresu edo bilerak antolatu.

- Gaiarekin zerikusia duten argitalpenak argitaratu eta funtsa dokumentalak mantendu eta sustatu.

- Eztabaida publikoa eta partehartze soziala sustatu.

Espainian Oinarrizko Errentaren inguruko eztabaida 1980. hamarkada inguruan hasi zen atzerriko egile ezberdinen eskutik eta 1990. hamarkadatik aurrera bertako egileak ere gaia jorratzen hasi ziren, eztabaida ugarituz. Ildo honetan, iritzi artikulu edo liburu ezberdinak argitaratu ziren eta jardunaldiak antolatzen hasi ziren.

Oinarrizko errentaren inguruko lehen gerturatze bat Malagan antolatu zen 1998an, eta bertan hartutako erabaki nagusietako bat izan zen Oinarrizko errentaren inguruko lehenengo jardunaldiak antolatzea. Horrela, urte horretan, Bartzelonan antolatu zen lehen jardunaldia. Jardunaldi horretatik ekimen ezberdinak sortu ziren, eta oinarrizko errentaren ideia Espainia guztira hedatzen hasi zen.

EAEri dagokionez, oinarrizko errentaren gaia mahai gainean jarri zela aprobetxatuz, 1996tik aurrera, bazterketa sozialaren kontra lan egiten zuten plataforma ezberdinek (Bizkaia Gogoa, Gipuzkoa Eraiki eta Laudio Elkartasuna) gerora Herritarren Oinarrizko Errenta moduan ezagutuko zen dokumentuaren inguruan lan egiten hasi ziren. Euren helburua hiritar guztiei enplegurako sarrera eta oinarrizko errenta bat bermatzea zen. Horrela, mobilizazio ezberdinen ostean, 2000. urtean herri ekimena jarraiturik onartu zen Herritarren Oinarrizko Errenta, baina aurretik azaldu diren mugekin.

\subsection{Oinarrizko Errenta Unibertsalaren ezaugarriak}

Behin definizioa eta aurrekariak aztertuta, Oinarrizko Errenta Unibertsalaz hitz egitean hurrengo ezaugarriak dituen kontzeptu batez hitz egiten da Moreno Márquezek bere liburuan (2008) azaltzen duen moduan: hiritarrek, inolako baldintzarik gabe, euren oinarrizko behar materialak asetzeko aldizkako diru kopuru bat jasotzeko duten eskubidea.

Oinarrizko errentek izan behar duten egiturazko ezaugarrien artean hurrengoak aipatzen dira:

- Banakakoa: banakakoei onartzen zaie eta ez familiei.

- Unibertsala: pertsona guztientzako da.

- Baldintzarik gabea: pertsonak dituen diru sarrerek ez dute mugatzen, eta ez du inolako harremanik lan merkatuarekin.

Ezaugarri hauez gain, aukera politikoko beste ezaugarri hauek aipatzen dira:

- Kopurua: pobreziaren muga gisa ezarrita dagoen kopurua izango da gutxienez jaso beharrekoa.

- Unibertsaltasuna: hiritar guztiei emango zaie zati bat modu pertsonalizatuan.

- Berdintasuna: pertsona guztiek diru kopuru berdina jasoko dute.

- Partehartzea: bi zatitan banatuko da Oinarrizko Errenta. Alde batetik, pertsonak ezarritako diru kopuruaren zati bat jasoko du, eta beste aldetik, geratzen den beste zatia, izaera publikoko inbertsioetarako erabiliko da (hezkuntza, osasuna, etxebizitza, etab.).

- Eraberritzea: Oinarrizko Errentak ia gainontzeko prestazio guztiak ordezkatuko ditu.

\subsection{Oinarrizko Errenta Unibertsalaren modelo ezberdinak}

Aurreko atalean Oinarrizko Errentaren ezaugarriak aztertu ditugu, eta irizpide horiei jarraituz, ereduak honela sailkatu daitezke (Moreno Márquez, 2008) [7. koadroa].

\subsection{Oinarrizko Errenta Unibertsalaren egokitasuna}

Ikusi dugun moduan, munduan zehar Oinarrizko Errentaren adibideak ez dira ugariak. Aldeko eta kontrako iritziak sortzen dituen gaia da, eta, lehenik eta behin, bakoitzaren argudioak azalduko ditut, Moreno Márquezek (2008) aipatzen duenari jarraituz (8. koadroa). 


\begin{tabular}{|c|c|c|c|}
\hline \multicolumn{4}{|c|}{ 7. koadroa. Oinarrizko Errenta Unibertsalaren eredu ezberdinak } \\
\hline Eredua & Izena & Kontzeptua & Alde onak edo mugak \\
\hline Fuertea & $\begin{array}{l}\text { Jatorrizko Oinarrizko Errenta } \\
\text { Eredua }\end{array}$ & $\begin{array}{l}\text { Aurrez aipatutako ezaugarri } \\
\text { guztiak betetzen dituen eredua da. } \\
\text { Oinarrizko Errenta gizarte bateko } \\
\text { pertsonek duten beharrak asetzera } \\
\text { bideratzen da, eta horregatik } \\
\text { banakako mailako beharrez } \\
\text { gain, maila kolektiboko beharrak } \\
\text { asetzera ere bideratzen da. }\end{array}$ & $\begin{array}{l}\text { Ereduaren bideragarritasun } \\
\text { finantzarian topatzen dira } \\
\text { mugak. }\end{array}$ \\
\hline \multirow[t]{4}{*}{ Ahula } & $\begin{array}{l}\text { Oinarrizko Errenta Unibertsala, } \\
\text { baina partziala }\end{array}$ & $\begin{array}{l}\text { Neurriaren unibertsaltasuna } \\
\text { aldarrikatzen da, baina } \\
\text { egikaritzeko egon daitezkeen } \\
\text { oztopoak direla eta, diru } \\
\text { kopuruaren zenbatekoa pobrezia } \\
\text { mugaren azpitik egotea onartzen } \\
\text { da, hasieran behintzat (Van } \\
\text { Parijs). }\end{array}$ & $\begin{array}{l}\text { Ez ditu betetzen oinarrizko } \\
\text { errentaren gutxieneko } \\
\text { baldintzak. }\end{array}$ \\
\hline & Partehartzerako errenta & $\begin{array}{l}\text { Oinarrizko errenta baldintzatuta } \\
\text { dago, hau da, norbanakoak } \\
\text { bermatuta izango du oinarrizko } \\
\text { errenta, baina ordainetan, } \\
\text { gizartean parte hartu beharko } \\
\text { du enplegu edo beste lan mota } \\
\text { baten bidez (Atkinson). }\end{array}$ & $\begin{array}{l}\text { Lan bat egiten ez duen pertsonak } \\
\text { ez du jasotzen OE. }\end{array}$ \\
\hline & Stakeholder Society & $\begin{array}{l}\text { Oinarrizko errenta unibertsala } \\
\text { eta baldintzarik gabea izango da, } \\
\text { baina diru kopuru bat hilero jaso } \\
\text { beharrean, kopuru guztia aldi } \\
\text { bakarrean jasoko da (Ackerman } \\
\text { eta Alstott). }\end{array}$ & $\begin{array}{l}\text { Diru kopuru guztia batera } \\
\text { jasotzen denez, ondo ez } \\
\text { erabiltzeko arrisku dago. }\end{array}$ \\
\hline & Zerga negatiboa & $\begin{array}{l}\text { Zergak ordaintzeko diru kopuru } \\
\text { bat ezartzen da. Minimo } \\
\text { horretara iristen ez denak ez } \\
\text { ditu zergak ordaintzen, baina } \\
\text { besteek bai. Minimora iristen ez } \\
\text { denak, minimo horretara iristeko } \\
\text { diru kopuru bat jasoko luke, eta } \\
\text { besteei berriz, OE deskontatu } \\
\text { egingo zaie errenta aitorpenean } \\
\text { (Milton Friedman). }\end{array}$ & $\begin{array}{l}\text { Azken urteetan planteatzen den } \\
\text { proposamenetako bat. }\end{array}$ \\
\hline
\end{tabular}

OE: Oinarrizko Errenta.

Iturria: Moreno Márquezen (2006) lanarekin abiatuta.

\section{8. koadroa. Oinarrizko Errenta Unibertsalaren inguruko iritziak}

\begin{tabular}{|c|c|}
\hline Aldeko arrazoiak & Aurkako arrazoiak \\
\hline $\begin{array}{l}\text { - Estigma murriztuko luke hiritar guztiek jasotzean, inor ez baita } \\
\text { markatuta sentituko. } \\
\text { - Pobrezia errotik ezabatuko luke, erosteko ahalmen txikia dutenen } \\
\text { egoera hobetuko bailuke, eta aberastasuna hobeto banatuko } \\
\text { litzateke. } \\
\text { - Lan merkaturako malgutasuna ekarriko luke, langileen askatasuna } \\
\text { ekarriko bailuke lan kontratuak negoziatzeko orduan, eta ez lukete } \\
\text { edozein lan edozein soldataren truke egitea onartuko. } \\
\text { - Ekintzailetza, auto enplegu eta berrikuntzarako aukerak zabalduko } \\
\text { lituzke. } \\
\text { - Hiru lan moten (ordaindua, boluntarioa eta etxekoa) banaketa } \\
\text { berria. } \\
\text { Bestelako gizarte laguntza gehigarriak desagertuko lirateke, eta } \\
\text { gizarte laguntzen inguruan dagoen iruzurra murriztuko litzateke. }\end{array}$ & $\begin{array}{l}\text { - Oinarrizko Errentak jendeak lanik ez egitera bultzatuko luke. Ondo- } \\
\text { rioz, lanerako hautua egin dezaten, enpresaburuek soldata hobeak } \\
\text { ordaindu beharko lituzkete, lanaren kostuak handituz, produktibi- } \\
\text { tatearen eta errentagarritasunaren kalterako. } \\
\text { - Inflazioa igoko luke, ekoizpen kostuak handitzean azken produk- } \\
\text { tuen prezioa igoko litzatekeelako. } \\
\text { - Immigrazioa nabarmen handituko luke. }\end{array}$ \\
\hline
\end{tabular}

Iturria: Moreno Márquez (2008), egileak itzulita.

Gai berria izan arren, aldeko eta aurkako iritziak sortzen dituela ikusi dugu. Ikerketa eta azterketa ezberdinak daude gaiaren inguruan, eta, azken aldian, bere bideragarritasun eta egokitasunaren inguruan hitz egiten da, gure gizartean aplikatzea posible den edo ez ikusteko. Proposamen ezberdinak daude horren inguruan, baina proposamen ezberdinak aztertu aurretik, ondorengo bi bideragarritasun mota landu behar direla argi izan behar da, Moreno Márquezek (2008) azaltzen duen moduan:

- Bideragarritasun sozial eta teknikoa: zentzu honetan bideragarritasuna lortu ahal izateko proposamenak eta ematen den informazioak argia, errealista, ulerterraza eta serioa izan behar du. Proposamenak bizi dugun errealitatea kontuan 
izan behar du, eta egoera horretara egokitu behar du. Proposamen berriekin gertatu ohi den moduan, hasieran normala izango da gizartean kontrako iritziak eta zalantzak egotea. Hau bideratu ahal izateko, informazio argia eman beharko da, eta aldi berean, eztabaida sustatu eta zalantzak argitzeko galdera ezberdinak planteatu beharko dira. Horrela, aurkakoak alde jartzea lortu daiteke, eta orokorrean egon daitezkeen galderak argitzea. Behin bideragarritasun soziala lortuta, errazago lortzen da bideragarritasun teknikoa, hau da, iritzi publikotik agenda publikora pasatzeko urratsa emango da. Bideragarritasun teknikoa lortzeko, beharrezkoa da alderdikeriak gainditzea, jarrera ireki eta ez baztertzaileak eraikiz.

- Bideragarritasun ekonomikoa: kezka eta zalantza gehien sortzen dituen bideragarritasuna da, gastu publikoa aldatzea ekartzen baitu. Oinarrizko Errenta Unibertsala aldezten dutenen arabera, errenta bideragarria izateko aukera bat baino gehiago daude; hala ere, gaur egungo proposamen gehienak gizarte laguntzetara bideratzen diren baliabideak beste modu batean antolatzean eta zerga sistema erreformatzean oinarritzen dira, zerga negatiboaren bidez. Aurreko atalean, Oinarrizko Errenta ereduak azaltzean aipatu den moduan, indar handia hartzen ari den proposamena da, eta funtsean, Estatuak errentaren gaineko zergaren bidez, herritarrei prestazio ekonomiko bat ematean datza. Ikerketa ezberdinak egin dira horren inguruan, eta horrelako erreforma fiskal batekin hiritarren \% 70ak onura bat jasoko lukeela ondorioztatzen da. Bideragarritasunaren eztabaida honetan errenta horrek zenbatekoa izan beharko lukeen finkatzeko garaian ere hainbat irizpide proposatzen dira. Batzuentzat pobreziaren muga hartzea litzateke egokiena, beste batzuentzat, aldiz, lanbide arteko gutxieneko soldataren portzentaje bat, gutxieneko pentsioaren parekoaren aldeko izan arren. Arlo horretan aurrerapauso handiak ematen ari dira, eta, azken aldian, simulagailu fiskal informatikoak erabiltzen dira makroekonomian izan dezakeen eragina aztertzeko.

\subsection{Oinarrizko Errenta Unibertsala gauzatzeko aukera}

Oinarrizko Errentaren alderdi ezberdinak landu ostean, errealitatean gauzatu daitekeen aukera den edo ez aztertuko da.

EAE mailan saiatuz gero, administrazio ezberdinen eta eskumen banaketen oztopoarekin aurkitzen gara. Aukera hau gauzatu ahal izateko, zergen kontuak landu behar dira batez ere, eta hemen, muga handi batekin topatzen gara. EAE mailan dagoen eskumen banaketa dela eta, prestazio ekonomikoen arloan gastuaren inguruko eskumena Eusko Jaurlaritzak du, baina diru bilketari dagokionez, Foru Aldundiek dute horren inguruko eskumena. Diputazio bakoitzak bere zergen arauak ditu, eta hori dela eta, hainbat puntutan desadostasunak edo puntu ezberdinak dituzte. Horrez gain, Foru Aldundi bakoitza alderdi politiko ezberdin baten eskuetan dago. Alderdi bakoitzak bere ideiak eta politikak ditu zergen arloan, eta oraingoz behintzat, ez dira ados jartzen politika bateratuak aurrera eramateko.

Gainera, Moreno Márquezek argitaratutako Realidad, presente y futuro de las políticas contra la exclusión social en el País Vasco (2009) artikuluan irakurtzen dugu politikoak gai honen inguruan informatzen eta hitz egiten hasi direla, baina oraindik mesfidati azaltzen direla gaiaren inguruan. Artikulu horretatik atera ditzakegun ondorio nagusiak hurrengoak dira:

- Orokorrean adostasuna azaltzen dute politikoek gaur egungo laguntza sistemaren inguruan. Gehienen ustez, ereduaren krisi bat ematen ari da, eta planteamendu berri bat egin behar da. Gune honetan Oinarrizko Errenta Unibertsalak bere lekua izan dezake.

- Oinarrizko errentaren inguruko eztabaida indartzen hasi den arren, proposamen honen kontra ematen diren argudioak ere agertzen dira politiko ezberdinen artean. Hala ere, ez daude eztabaidara itxita, nahiz eta aurrerapausoak emateko baldintza malguagoak eta bideragarritasun sozial zein politikoa behar diren.

- Bideragarritasun tekniko eta ekonomikoa ere beharrezkoak dira pausoak emateko.

Arrazoi hauek direla eta, oso zaila izango litzateke une honetan EAE mailan oinarrizko errenta, bateratua martxan jartzea. Aipatu dugun bezala, alde batetik eskumenen mugekin topatuko ginateke eta, beste aldetik, alderdi politiko ezberdinen arteko interesa eta adostasuna bilatzea zaila izango litzateke.

Maila politikoan, oinarrizko errentaren inguruko interesa azaldu duen alderdi bakarrenetako bat Bildu izan da. Gaur egun, Gipuzkoako Foru Aldundia Bildu alderdi politikoaren esku dago eta hori aprobetxatuz, oinarrizko errenta Gipuzkoa mailan planteatzeko aukera dago.

Hala ere, aukera egon arren, aldaketak egin beharra dago zergen arloan, eta gizarte arloan batez ere. Hori dela eta, biztanleri osoari eragingo ziokeen planteamendu bat egin beharrean, biztanleriaren sektore baten gainean izango lukeen eragina aztertuko dut. Azterketa honetarako hartuko dugun biztanleri sektorea, 18-25 urte bitarteko gazteria da. Populazioaren zati honen ezaugarriak hurrengoak dira (Eustat):

- Gipuzkoako biztanleri osoaren \% 7,2 da 18-25 urte bitarteko biztanleria ( 50.582 pertsona).

- Lanari erreparatuz gero, langabezia tasa osoaren $\%$ 8,35 dira, eta euren adin tarteari dagokionez, $\%$ 11. Adin tarte honetako pertsonen gehiengoa une honetan ikasten ari da, hau da, \% 66.

- Emantzipazioaren atalean, \% 89,35 gurasoen etxean bizi da, nahiz eta hautatzeko aukera izanez 
gero, \% 79,6 familiarena ez den etxe batean biziko litzateke.

- Egoera ekonomikoari dagokionez, 15-29 urte arteko gazteen gehiengoak, hau da, $\% 73,2 \mathrm{k}$, $300 €$ baino gutxiagoko diru sarrerak ditu. Etxebizitza egoerari ere erreparatuz gero, familiaren etxetik kanpo bizi diren gazteen erdiak baino gehiagok $900 €$ baino diru sarrera txikiagoak ditu.

Datu orokor hauekin ageriko dira gazteek emantzipatzeko dituzten zailtasunak, eta horrek bai gazteengan bai gizartean ditu ondorio ezkorrak. Alde batetik, emantzipatzeko zailtasunak direla eta, gurasoen edo familiaren etxean bizitzen jarraitzen dute, eta ondorioz, familiarentzat zama bihurtzen dira. Beste aldetik, egoera ekonomiko kaltebera izan ohi dute, eta askok, emantzipatzeko hautua egin arren, familiaren laguntza behar dute. Langabezia tasa ere oso garaia da gazteen artean. Lehen lana aurkitzeko zailtasun handiak daude, eta horregatik, gazte askok ikasten jarraitzeko erabakia hartzen dute. Hala ere, ikasten jarraitzeko dirulaguntzak edo bekak murritzak dira, eta ondorioz, familiaren kargu geratzen da kostu hori ere. Guzti honekin oso gazte kualifikatuak aurki ditzakegu, baina lan esperientzia gabekoak, eta inolako autonomiarik lortu gabe (arlo ekonomikoari eta familiarrari dagokionez).

Gaur egun Eusko Jaurlaritzaren zein Gipuzkoako Foru Aldundiaren eskumen diren dirulaguntzak jaso ahal izateko, baldintza batzuek eskatzen dira adinari eta bizikidetza unitateari dagokionez (9. koadroa).

\begin{tabular}{|c|c|c|}
\hline \multicolumn{3}{|c|}{$\begin{array}{l}\text { 9. koadroa. EAEko dirulaguntzak jasotzeko baldintza } \\
\text { nagusiak }\end{array}$} \\
\hline $\begin{array}{l}\text { Diru sarrerak } \\
\text { bermatzeko errenta }\end{array}$ & $\begin{array}{l}\text { Gizarte } \\
\text { larrialdietarako } \\
\text { laguntzak }\end{array}$ & $\begin{array}{l}\text { Diru sarrerak } \\
\text { bermatzeko } \\
\text { laguntza }\end{array}$ \\
\hline $\begin{array}{l}\text { - Salbuespenak sal- } \\
\text { buespen, urtebete } \\
\text { lehenagotik bizi- } \\
\text { kidetza unitatea } \\
\text { (BU) osatzea. } \\
\text { - } 23 \text { urte baino } \\
\text { gehiago izatea. } \\
\text { Arauak salbues- } \\
\text { penak ere biltzen } \\
\text { ditu. }\end{array}$ & $\begin{array}{l}\text { - Gutxienez, } \\
\text { eskabidea } \\
\text { aurkeztu baino } \\
\text { urtebete lehenago } \\
\text { sortutako biziki- } \\
\text { detza unitatea iza- } \\
\text { tea, salbuespenak } \\
\text { salbuespen. } \\
\text { - } 18 \text { urte izatea, } \\
\text { salbuespen } \\
\text { batzuekin. }\end{array}$ & $\begin{array}{l}\text { - Elkarbizitza } \\
\text { independenteko } \\
\text { unitate bat osa- } \\
\text { tzea, gutxienez } \\
\text { eskaera aurkezten } \\
\text { denetik urtebete } \\
\text { baino lehenago, } \\
\text { Diru Sarrerak Ber- } \\
\text { matzeko lagun- } \\
\text { tzako kolektiboak } \\
\text { salbuetsita. } \\
\text { Gipuzkoako } \\
\text { lurralde histo- } \\
\text { rikoan erroldatua } \\
\text { egon eta bene- } \\
\text { tako egoitza iza- } \\
\text { tea, eskaera data } \\
\text { baino sei hilabete } \\
\text { lehenagotik } \\
\text { gutxienez. }\end{array}$ \\
\hline
\end{tabular}

Iturria: Egileak egina.

Erroldako baldintza izan ezik, Diru sarrerak Bermatzeko Laguntzarako eta Errentarako baldintza berak eskatzen dira.

Baldintza horietan ikusten den moduan, hiru laguntzek antzeko baldintzak dituzte. Kasu guztietan urtebeteko bizikidetza independentea eskatzen da, eta beste batzuetan, 23 urte baino gehiago izatea eskatzen da. Baldintza horiek ikusirik, eta aurrez euskal gazteriaren inguruan ematen diren ezaugarriekin loturik, gazteen gehiengoa prestazio ekonomikoak eskatzeko eskubidetik kanpo geratzen dela ondorioztatzen da.

Egoera horri aurre egiteko, Gipuzkoa mailan 18-23 edo 18-25 urte bitarteko gazteentzat Oinarrizko Errenta Unibertsala eratzea proposatzen dut. Horren bitartez, aurrez aipatutako arazoei aurre egin eta gazteriak bizi duen egoerari erantzuteko aukera egongo litzateke.

Oinarrizko Errenta Unibertsal bat finantzatzeko egon daitezkeen aukera ezberdinen inguruan ikerketa ugari egin dira, eta batez ere, bi moduren inguruan hitz egin da. Rafael Pinilla eta Luis Sanzok (2004) horren inguruko azterketa sakon bat egin zuten 2004ean, eta lortutako ondorio nagusiak hauek dira:

- Oinarrizko beharrak asetzera bideratu beharreko diru kopurua ez dago zehaztuta. Lehenik eta behin, pobreziaren neurketarako baliagarria izango den neurketa ofizial bat definitzea beharrezkoa izango litzateke, baina bitartean, Kontribuzio Gabeko Pentsioen kopurua hartzen da oinarri gisa. Hala ere, autonomia erkidego bakoitzak pentsio horren osagarriak ezartzeko aukera izango du, erkidego guztietako bizi maila ez baita bera.

- Oinarrizko errenta jaso ahal izateko ez da derrigorrezko baldintza lanerako prest egotea, baina pizgarriak sortze aldera, lanean ari diren pertsonentzako hobariak ezarriko dira.

- Arlo fiskalari dagokionez, Oinarrizko Errenta Unibertsala kudeatzeko modurik egokiena Errentaren Gaineko Zergan izaera negatiboko zerga txertatzea da. Modu honetara diru sarrerarik ez duten pertsonei oinarrizko errenta bat bermatuko zaie, eta errenta baxuenentzako osagarri bat ezarriko da. Gainera, errenta kopuru bat gainditzen dutenentzako zerga arintze bat ekarriko du. Arlo fiskalari jarraituz, interes tasa bakarra ezarri beharko litzateke. Zerga hau \% 5oean kokatuko litzateke, baina oinarrizko gutxiengoa eta laneko pizgarriak kendu ostean. Horren ondorioz, soilik, errenta garaienei eragingo lioke.

Ondorio nagusi horiek kontuan hartu eta gaur egun Gipuzkoako Foru Aldundiak arlo fiskalaren inguruan hartu duen ildoa aztertuz, Oinarrizko Errenta Unibertsala gauzatzeko bide posible batean aurkitzen garela esan daiteke. Aldundiak arlo fiskalaren inguruan hartu dituen erabakien artean hurrengoak aurkitzen dira:

- Tasa marjinalaren tarteak errenta handienetan zabaldu egin ditu: \% $4565.000 €$ tik gora, $\% 47$ $120.000 €$ tik gora, eta \% $50175.000 €$ tik gora.

- Ondarearen gaineko Zerga berrezarri da, eta horrela Aberastasunaren eta Fortuna Handien gaineko Zerga indarrean jarri da. 
- Adinarengatik, ondorengoengatik eta aurrekoengatik egiten ziren murrizketak \% 2 jaitsi dira.

- Gipuzkoan gaur egun arlo fiskalean dugun errealitatea ikusita eta Oinarrizko Errenta Unibertsal baterako behar diren ezaugarriak landuta, gazteen arloan ematen diren eta aurrez aipatu ditugun arazoei aurre egiteko hurrengo proposamena garatu daiteke:

Balizko proposamen honetan bi aukera aztertuko ditut: 1) 18-23 urte bitarteko gazteentzako Oinarrizko Errenta Unibertsala, eta 2) 18-25 urte bitarteko gazteentzako Oinarrizko Errenta Unibertsala. Bi aukerentzako finantzazioa bidea bera izango da, eta, beraz, ezberdintasuna gastu ekonomikoa izango da.

Bi aukerentzako ezaugarri komunak hurrengoak izango dira:

- Oinarrizko Errenta Unibertsalerako oinarrian hartuko den diru kopurua gaur egungo kontribuzio gabeko pentsioen kopurua izango da, hau da, $364,90 €$.

- Pertsona Fisikoen Errentaren gaineko Zerga aplikagarrien tasa marjinalen aldaketa.

Aldaketa honekin 14.951.00o,2 € gehiago lortuko lirateke.

Ondarearen gaineko zergari dagokionez, 2011ko abenduaren 26an Ondarearen gaineko Zerga berrezartzea erabaki zen, eta horrela, Aberastasunaren eta Fortuna Handien gaineko Zerga indarrean jarri zen berriro ere. Aldaketa honekin 8,7 miloi euro gehiago biltzea aurreikusten da.

Ezaugarri hauek kontuan hartuta, proposamenari ondorengo moduan eragingo lioke (2. taula).

Taula honetan ikusten den moduan, bi proposamenak bideragarriak dira. Ondarearen gaineko Zergaren inguruan oraingoz ez da gehikuntzarik planteatzen, urte honetan ezarri baita arau berria indarrean. Hori dela eta, hurrengo urteei begira, arlo honetatik fiskalizatzeko aukera ematen du mozkin guztiak Pertsona Fisikoen Errentaren gaineko Zergaren (PFEZ) gainean izan beharrean.

Proposamen honek aurrera eginez gero, hurrengo ondorio eta onurak lortzeko aukera egongo da:

- PFEZn egiten den aldaketak, 10.706 pertsonetan eragingo luke, hau da, erreta aitorpena egiten dutenen \% 0,3ari, eta Ondarearen gaineko zergak 857 pertsona berriri eragitea aurreikusten da, hau da, Gipuzkoako biztanleriaren \% 0,1ari. Onura aldiz, Gipuzkoako biztanleriaren \% 5,14ak jasoko luke lehenengo kasuan eta \% 7,17ak bigarren kasuan (1. grafikoa).

- Alderdi sozial eta ekonomikoari dagokionez, aurrez aipatutako arazoei aurre egiten lagunduko du, eta ondorioz, alderdi ezberdin batzuetan eragingo du (10. koadroa).

\section{Ondorio eta proposamenak}

Oinarrizko errentaren inguruko alderdi teorikoa eta praktikoa landu ostean, hurrengo ondorio nagusi hauek nabarmenduko nituzke.

\subsection{Ondorio nagusiak}

Hasteko, Bazterketaren definizioan etxebizitza eta lanaren faktoreak gizarteratzearen adierazle gisa erabiltzen dira. Dirulaguntzen bilakaera aztertzean ikusi da adierazle horiek gizarteratzearen erakusle ezin direla izan, 18/2008 Legearen berrikuntza nagusia, dirulaguntzen barruan bi adierazle horiek sartzea izan baita. Hala ere, lana eta etxebizitza izateak pertsona bat gizarteratuta dagoela esatera ezin gaitu

1. taula. Oinarrizko Errenta Unibertsal posible bat

\begin{tabular}{|l|c|c|c|c|c|}
\hline $\begin{array}{l}\text { Oinarria } \\
\text { (milaka eurotan) }\end{array}$ & $\begin{array}{c}\text { Gaur egun } \\
\text { aplikatzen den (\%) }\end{array}$ & $\begin{array}{c}\text { Lortzen den etekina } \\
\text { (milaka eurotan) }\end{array}$ & $\begin{array}{c}\text { Oinarria } \\
\text { (milaka eurotan) }\end{array}$ & $\begin{array}{c}\text { Proposamena } \\
\text { (\%) }\end{array}$ & $\begin{array}{c}\text { Lortutako balizko } \\
\text { etekina (milaka } \\
\text { eurotan) }\end{array}$ \\
\hline $64.970-120.000$ & 45 & 200.930 & $64.970-90.000$ & 45 & 134.005 \\
\hline $120.000-175.000$ & 47 & 52.323 & $90.000-150.000$ & 50 & 100.360 \\
\hline$>175.000$ & 50 & 80.444 & $>150.000$ & 55 & 99.332 \\
\hline
\end{tabular}

Iturria: Egileak egina, Gipuzkoako Foru Aldundiko Ogasun departamentuko 2011ko datuekin.

2. taula. Aberastasunaren eta Fortuna Handien gaineko Zerga berriaren eragina

\begin{tabular}{|l|c|c|c|c|}
\cline { 2 - 5 } \multicolumn{1}{c|}{} & Biztanle kopurua & $\begin{array}{c}\text { Oinarriko Errenta } \\
\text { Unibertsalaren kostua } \\
\text { (eurotan) }\end{array}$ & $\begin{array}{c}\text { PFEZaren bidez } \\
\text { lortutako mozkina } \\
\text { (eurotan) }\end{array}$ & $\begin{array}{c}\text { Ondarearen gaineko } \\
\text { Zergaren bidez lortutako } \\
\text { mozkina (eurotan) }\end{array}$ \\
\hline $18-23$ urte & 36.277 & $13.237 .477,3$ & $14.951 .000,2$ & 8.000 .000 \\
\hline $18-25$ urte & 50.582 & $18.457 .371,8$ & $14.951 .000,2$ & 8.000 .000 \\
\hline
\end{tabular}

PFEZ: Pertsona Fisikoen Errentaren gaineko Zerga.

Iturria: Egileak egina. 
1. proposamena

2. proposamena

Ondarea

Errenta

Iturria: Egileak egina.

10. koadroa. Oinarrizko Errenta Unibertsal proposamenaren eragin kualitatiboa

\begin{tabular}{|l|l|}
\hline Emantzipazioa & $\begin{array}{l}\text { Diru sarrera ziur bat izanda emantzipatzeko aukera handitu egingo da, eta horrela, familiaren babesean bizitzetik, modu } \\
\text { autonomo batean bizitzera pasatzeko aukera dago. Horrela, familiengan ematen den estaldura zama arindu egingo da, } \\
\text { eta gizarte mailan ematen den izaera paternalistarekin amaitzen hasiko da. }\end{array}$ \\
\hline Lana & $\begin{array}{l}\text { Lan eskas bat dutenen egoera hobetuko da, eta aldi berean, lan eskas horien aurrean negoziatzeko aukera ere handitu } \\
\text { egingo da, ziurtasun ekonomiko batekin jokatzeko aukera ematen baitu. }\end{array}$ \\
\hline Ikasketak & $\begin{array}{l}\text { Lana eta ikasketak uztartzeko aukera handiagoa ematen du, eta baita ere ikasketetan soilik zentratzeko aukera izatea. } \\
\text { Zenbait kasutan ikasketak ordaindu ahal izateko lana egin behar denez, horrek ikasketa erritmoa mantsotzea ekartzen } \\
\text { du, biak uztartu nahi izatean. Diru sarrera bat ziurtatua izanda, soilik ikasketak egiteko aukera egon daiteke lan eta } \\
\text { esfortzu guztiak horretara bideratuz gero. }\end{array}$ \\
\hline Autonomia & $\begin{array}{l}\text { Emantzipazioak eta familiatik ateratzeak gazteen autonomia lantzeko aukera emango du. Honela, gazte autonomoagoak } \\
\text { lortuko ditugu, bai alderdi ekonomikoari dagokionez, baina baita alderdi sozialari dagokionez ere. }\end{array}$ \\
\hline Demografia & $\begin{array}{l}\text { Gaur egun, familia osatzeko adina asko atzeratzen da emantzipatzeko dauden arazoak direla eta. Emantzipazioaren } \\
\text { arazoari erantzunez gero, bizitza planari lehenago heltzeko aukera egongo da. Horrela, familia bat osatzeko ematen } \\
\text { den adina murriztu daiteke, eta aldi berean, jaiotza kopurua ere handitu daiteke. Horren ondorio zuzena izango da } \\
\text { jaiotza tasan eta demografiaren bilakaeran. Demografia jaisten ari den une honetan, oso garrantzitsua da jaiotza tasan } \\
\text { eragitea. }\end{array}$ \\
\hline Etorkizuna & $\begin{array}{l}\text { Epe luzera begira, pentsio sisteman ere eragina izango du. Gaur egungo demografia jaitsierarekin eta jaiotza tasa } \\
\text { baxuarekin sistema hau mantentzeko eta ziurtatzeko zailtasunak egon daitezke. Aurreko puntuan aipatu dugun } \\
\text { moduan, egoera hori aldatzeko oinarri bat emango liguke Oinarrizko Errenta Unibertsalak, eta horrela pentsio sistema } \\
\text { bermatzeko aukerak ugarituko dira. }\end{array}$ \\
\hline
\end{tabular}

Iturria: Egileak egina.

eraman. Alde batetik, lan eskas edo soldata duin gabeko pertsona ugari daude, eta, beraz, horri erantzun ahal izateko sortu da laneko diru sarrerak osatzeko errenta modalitatea. Beste aldetik, etxebizitzak merkatuan dituzten prezioak ikusirik (bai alokairuan bai salmentan) eta askok gastu horiei aurre egiteko dituzten zailtasunei erantzuteko, Gizarte Larrialdietarako Laguntzak zein Etxebizitza Gastuetarako Prestazio Osagarriak kontzeptu horietan prestazio ekonomiko bat dute.

Hori guztia kontuan izanik, Ikusi dugun moduan, pertsona askok zailtasunak dituzte alor horretan, eta ez babes sistemarik ezean, asko egongo lirateke bazterkeriaren mugan egoteko arriskuan.
Jarraitzeko, dirulaguntzek funtsean eskubide, banakotasun, izaera integrala bezalako printzipioez hitz egiten dutela aipatu dugu, baina praktikan, ez direla betetzen edo modu mugatuan betetzen direla ikusi da. Dispositiboaren gabeziak azaltzerakoan aipatu den moduan, balizko onuradunetara iristeko zailtasunak daude. Informazio falta, sistemaren konplexutasuna, administrazioaren aldetik ematen den kontrola, zabalduta dagoen estigma elkartzen dira, eta horrek herritarren artean desberdintasun horizontal nahiz bertikalak gertatzea dakar.

Ondorioz, oinarrian bilatzen edo aipatzen diren printzipioak ez dira lortzen, eta urteetan eman diren 
aldaketek ere, ez diote arazo honi errotik heldu. Aldaketak eman diren garaian printzipio hauek lehentasun izan beharrean, bestelako kontrol edo penalizazio neurriak hartzera jo da.

Honez gain, dirulaguntzetan eman den aldaketa nagusia gizarteratze aktiboaren filosofiaren txertaketa izan da, baina teorian egokia dela iruditu arren, praktikan ez da horrela gertatu. Gizarteratzea eskubide gisa planteatzen du sistema honek, baina errealitatean, kontraprestazio gisa erabili da. Kapitalismoaren gizartean bizi garen honetan, zerbait lortu ahal izateko irabazi egin beharraren ideia dago zabalduta, hau da, dirulaguntzak jaso ahal izateko, kontraprestazioan gizarteratze aktiboaren ildoan lan egin behar da. Honela, gizarteratzea eskubide bat izatetik, dirulaguntzak jaso ahal izateko betebehar bat izatera igarotzen da. Testuan zehar errepikatu den moduan, gizarteratze aktiboa enpleguarekin soilik lotu izan da, bere kontzeptu zabala alde batera utziz, eta ondorioz, kasu askotan ez da eraginkorra izan. Gizarteratze aktiboaren tresna nagusia gizarteratzeko hitzarmena da. Hitzarmen horiek, esan den moduan, gizarteratze tresna dira, baina gizarteratze aktiboaren filosofiak hartu duen dimentsioa dela eta, kontrol tresna bihurtu dira. Azaldu den moduan, gizarteratzea eskubide bat izatetik betebehar bat izatera pasa da, eta horren ondorioz, hitzarmenak eskubide hori gauzatzeko tresna izatetik, betebeharra betetzen den jakiteko kontrol tresna izatera igaro dira.

Ondorio hauetatik bazterketa eta pobrezia egoerari erantzun integral bat ez zaiola ematen esan daiteke. Arazo honi aurre hartzeko neurri gisa, Oinarrizko Errenta Unibertsala planteatu da, eta erantzun egokia izan daitekeela ikusi dugu.

Oinarrizko Errenta Unibertsal batek baieztatu ditugun gabezia eta arazo horiei erantzun bat emateko balioko luke, oinarrian printzipio eta ezaugarri horiek dituelako, eta indarrean dagoen tokietan erantzun egoki bat lortu delako.

Eredu hau martxan jarri ahal izateak bideragarritasun tekniko, sozial eta ekonomikoa eskatzen du, eta zailtasunak plano honetan ikusten dira. Proposamen honek aldaketa ekonomikoa, politikoa, interes aldaketa edo gizarte aldaketa eskatzen du, eta bide horretan lortu beharreko adostasunetan eman daitezke eztabaida handienak.

Hala ere, ikusi dugun moduan, arlo batzuetan aldaketa txiki batzuk eginez bideragarria izan daitekeen proposamena da, eta Ongizate Estatu honetan gizarteratze aktibo filosofiak eta diru laguntza sistemak benetan lortu nahi dituen helburuetara gerturatzen lagunduko luke.

\subsection{Gomendioak}

Lanean zehar ikusi den moduan, eta hipotesietan baieztatu den bezala, gaur egun dugun babes sistema ez da iristen markatutako helburuak lortzera, eta ondorioz, ez dio bazterketa eta pobreziaren arazoari erantzun oso bat ematen.

Gaur egun agenda politikoan dauden helburu horiek lortzeko bidean, Oinarrizko Errenta Unibertsala aukera bat izan daitekeela ikusi da azterketan zehar. Errenta honen ezaugarrietan eta jarraitzen dituen helburuetan, pobreziaren murrizketa, unibertsaltasuna, berdintasuna eta beste batzuk aipatzen dira, eta beraz, printzipio hauek eta gaur egungo sistemak bilatzen dituen helburu eta printzipioek ez dute talkarik egiten. Eztabaida handiena baldintzarik gabe izatearen printzipioak sortzen du. Gizarteratze aktiboaren filosofiarekin bateragarria den edo ez jartzen da balantzan, eta sistema honek gaur egun dugun gizarte ereduarekin bateragarria den edo ez.

Oinarrizko Errenta Unibertsalaren aurkakoen argudioetan enplegurako motibazio eza, immigrazioaren gorakada edo inflazioaren gorakada aipatzen dira, baina gaur egungo babes sistemari egiten zaizkion kritiken artean ere antzeko argudioak topatzen dira.

- Dirulaguntzen azken erreforma gizarteratze aktiboaren eta lanerako motibazioaren ildotik egin zen, baina ikusi den moduan, emaitzak ez dira lortu.

- Immigrazioaren gorakada aipatzen da, baina dirulaguntzetan aldaketak ematen direnean edo dirulaguntza berriren bat sortzen bada, beti erabiltzen den argudioa da hori. Immigrazioaren Euskal Behatokiaren arabera, EAE mailan 2009tik atzerritarren kopurua biztanleri kopuru osoaren $\% 6$ eta $\% 7$ artekoa da. Egia da 1990. hamarkadatik hona kopurua igo egin dela ,baina azken urteetan mantendu egin da, eta dirulaguntza sisteman aldaketak egon dira. Gainera, EAEko datu estatistiko osoak begiratuz gero, atzerritarrak azken urteetan igo egin direla ikusten da, baina baita jaiotza tasa, biztanleria tasa, hainbat zerbitzuetan zegoen eskariari erantzuteko eskulana, kotizazio tasa, etab.

- Inflazioaren gorakada bat eman litekeen edo ez jakiteko, gaur egun aurrerapen informatiko asko daude, baita ere simulagailu informatikoak. Beraz, ikusi egin beharko litzateke hori horrela izango ote den edo ez, eta honek gizartearen osotasunean zein eragin duen.

Aldaketa guztiak beraien esparru txikian izan dezaketen eragina ikusi beharrean, ikuspegia zabaldu eta maila oso eta zabal batean izan dezaketen eragina aztertu behar da.

Azkeneko zatian azaldu den moduan, aldaketa batzuk eginez posible da Oinarrizko Errenta Unibertsala bat martxan jartzea Gipuzkoa mailan. Bideragarritasun finantzariari dagokionez, arlo fiskalean aldaketa batzuk eginez posible dela ikusi da (Foru Aldundia bide horretatik doa, gainera). Egia da hasiera batean biztanleriaren zati batentzako bakarrik planteatu dela (gazteria), baina berrikuntza hori aldaketa txiki 
bat besterik ez da arlo fiskalean. Bideragarritasun tekniko eta soziala lortzeko bidean, proposamen egokia izan liteke aldaketa txikiekin eta biztanleriaren zati txiki batekin hastea. Honek berrikuntza gutxika barneratzea ekarriko luke, eta aldi berean, aldaketak pixkanaka onartzea eta banakako eragina bat batekoa izan beharrean, apurka onartzeko aukera emango luke. Proposamen berriekin edo aldaketekin jendearen mesfidantza eta ezetza zabaldu ohi da, eta neurri berriaren txertaketa bide honetatik egiteak sentimendu horiek lantzeko aukera emango luke, bideragarritasun soziala lortzeko bidea erraztuz. Behin bideragarritasun soziala lortuta, teknikoa lortzea errazagoa izan daiteke.

\section{Aipatutako bibliografia}

AGUILAR, M.; LAPARRA, M.; eta GAVIRIA, M. (1996): "Programas de renta mínima de inserción en España 1989-1995”, in ZENBAITEN ARTEAN, Pobreza, necesidad y discriminación. II Simposio sobre Igualdad y Distribución de la Renta y la Riqueza, Madril, Fundación Argentaria; Editorial Visor.

- (1995): La caña y el pez. Estudio sobre los salarios sociales en las comunidades autónomas, 1989-1994, Madril, Fundación Foessa.

ARARTEKOA (2013): Informe anual al Parlamento Vasco 2012 / Eusko Legebiltzarrarentzako urteko txostena 2012, Informes Anuales-Urteko Txostenak saila, Vitoria-Gasteiz, Eusko Jaurlaritza.

ARRIBA, A. (1999): Procesos de implantación de póliticas de rentas mínimas de inserción en España, Documentos de Trabajo saila, 9909. zb., Madril, CSIC [<http://digital.csic.es/ bitstream/10261/1559/1/dt-9909.pdf>].

AYALA, L. (2000): Las rentas mínimas en la reestructuración de los Estados de bienestar, Madril, Consejo Económico y Social.

- (1994): “Los sistemas generales de rentas mínimas en Europa: logros, límites y alternativas", Documentación Social, 96. zb., 223-276 or.

BASIC INCOME EUROPEAN NETWORK (d.e.): [<http://www. basicincome.org/bien/>].

CALVO, R.; eta LERMA, I. (2009): "Políticas activas de empleo en tiempo de crisis: una visión crítica desde lo local", Lan Harremanak, 20-21. zb., 227-250 or.

ESPAINIA (1978): “Constitución Española”, Estatuko Aldizkari Ofiziala, 1978ko abenduaren 29koa, 311. zb., 29.313-29.424 or.

EUROPA BATASUNEKO KONTSEILUA (1992): “Recomendación del Consejo, de 24 de junio de 1992, sobre los criterios comunes relativos a recursos y prestaciones suficientes en los sistemas de protección social (92/441/CEE)", Diario Oficial de la Unión Europa, L 245, 1992-8-26, 46-48 or.

EUSKAL AUTONOMIA ERKIDEGOA (2011a): “4/2011 Dekretua, urtarrilaren 18koa, Gizarte Larrialdietarako Laguntzei buruzkoa", Euskal Herriko Agintaritzaren Aldizkaria, 27. zb., 2011-2-9.
- (2011b): “4/2011 Legea, azaroaren 24koa, Gizarteratzeko eta Diru Sarrerak Bermatzeko Legea aldatzen duena", Euskal Herriko Agintaritzaren Aldizkaria, 233. zb., 2011-12-12.

- (2010): “147/2010 Dekretua, maiatzaren 25ekoa, DiruSarrerak Bermatzeko Errentari buruzkoa", Euskal Herriko Agintaritzaren Aldizkaria, 114. zb., 2010-6-17.

- (2008a): “8/2008 Legea, ekainaren 25ekoa, Gizarte Bazterkeriaren aurkako Legea eta Gizarte Eskubideen Agiriaren Legea aldatzekoa", Euskal Herriko Agintaritzaren Aldizkaria, 127. zb., 2008-7-4.

- (2008b): “18/2008 Legea, abenduaren 31koa, Gizarteratzeko eta diru-sarrerak bermatzekoa", Euskal Herriko Agintaritzaren Aldizkaria, 250. zb., 2008-12-31.

- (2008c): “12/2008 Legea, abenduaren 5ekoa, Gizartezerbitzuei buruzkoa", Euskal Herriko Agintaritzaren Aldizkaria, 246. zb., 2008-12-24.

- (2007): “4/2007 Legea, ekainaren 22koa, Gizarte Bazterkeriaren aurkako maiatzaren 22ko 12/1998 Legea eta Gizarte Eskubideen Agiriaren abenduaren 27ko 10/2000 Legea aldatzekoa", Euskal Herriko Agintaritzaren Aldizkaria, 134. zb., 2007-7-12.

- (2004): “64/2004 Dekretua, apirilaren 6koa, zeinaren bidez onartu baita Euskal Autonomia Erkidegoko gizarte zerbitzuen erabiltzaileen eta profesionalen eskubide eta betebeharren gutuna, eta iradokizunen eta kexen araubidea", Euskal Herriko Agintaritzaren Aldizkaria, 76. zb., 2004-4-23.

- (2003): “4/2003 Legea, ekainaren 25ekoa, Gizarte Bazterkeriaren Aurkako Legea aldatzen duena”, Euskal Herriko Agintaritzaren Aldizkaria, 137. zb., 2003-7-14.

- (2002): “199/2002 Dekretua, uztailaren 30ekoa, baztertuta dauden edo baztertuta geratzeko arriskuan dauden pertsonak laneratzeko Auzolan Programa arautzen duena", Euskal Herriko Agintaritzaren Aldizkaria, 174. zb., 2002-9-13. 
- (2001a): “Agindua, 2001eko otsailaren 14koa, Justizia, Lan eta Gizarte Segurantza sailburuarena, oinarrizko errentaren titularrentzat eta gizartelarrialdietarako laguntzen onuradunentzat lanean hasteko pizgarriak ezartzeko dena", Euskal Herriko Agintaritzaren Aldizkaria, 37. zb., 2001-2-21.

- (2001b): "8/2000 Legea, azaroaren 10ekoa, Gizarte Bazterkeriaren Aurkako Legea aldatzekoa", Euskal Herriko Agintaritzaren Aldizkaria, 1. zb., 2001-1-2.

- (2000a): “1/200o Dekretua, urtarrilaren 11koa, Gizarteratzeko Hitzarmenak arautzeko dena", Euskal Herriko Agintaritzaren Aldizkaria, 20. zb., 2000-1-31.

- (2000b): “10/200o Legea, abenduaren 27koa, Gizarte Eskubideen Agiriarena”, Euskal Herriko Agintaritzaren Aldizkaria, 249. zb., 2000-12-30.

- (1998): “12/1998 Legea, maiatzaren 22koa, Gizarte Bazterkeriaren aurkakoa”, Euskal Herriko Agintaritzaren Aldizkaria, 105. zb., 1998-6-8.

- (1996): “5/1996 Legea, urriaren 18koa, Gizartezerbitzuena, Euskal Herriko Agintaritzaren Aldizkaria, 218. zb., 1996-11-12.

- (1990): "2/199o Legea, maiatzaren 3koa, Gizarteratzeko Gutxieneko Dirusarrerei Buruzkoa”, Euskal Herriko Agintaritzaren Aldizkaria, 106. zb., 1990-5-30.

- (1989a): “39/89 Dekretua, otsailaren 28koa, Familiaren Gutxienezko Dirusarrera ematea araupetzen duena”, Euskal Herriko Agintaritzaren Aldizkaria, 44. zb., 1989-2-28.

- (1989b): “64/1989 Dekretua, martxoaren 21ekoa, Gizarteko Larrialdi egoeretarako diru Laguntzak arautzen dituena”, Euskal Herriko Agintaritzaren Aldizkaria, 6o. zb., 1989-3- 30.

EUSKO JAURLARITZA (1989): 1988-1992 Pobreziaren Aurkako Osoko Plana, Vitoria-Gasteiz, Eusko Jaurlaritza.

- (1986): Euskadiko gizarte-arloko egoera txarrei buruzko azterlana, Vitoria-Gasteiz, Eusko Jaurlaritza.

EUSTAT (d.e.) [〈http://www.eustat.es〉].

EUZÉBY, C. (1991): “La renta mínima en los países de la Comunidad Económica Europea. Experiencias y perspectivas", in BETOLAZA, J. I. (koord.), Nuevas necesidades, nuevas prestaciones. Cuartas Jornadas de Economía de los Servicios Sociales. Vitoria-Gasteiz, 21 al 23 de marzo de 1990, Barcelona, Asociación de Economía de la Salud.

GIPUZKOA (2012): “2012ko abenduaren 18ko 10/2012 Foru Araua, Aberastasunaren eta Fortuna Handien Gaineko Zergarena”, 243. zb., 2012-12-21.

JUSTIZIA, LAN ETA GIZARTE SEGURANTZA SAILA (2008): 1984-2008: 25 años de estudio de la pobreza en Euskadi. Síntesis de los estudios y trabajos estadísticos desarrollados entre 1984 y 2008 por el Departamento de Justicia, Empleo y Seguridad Social del Gobierno Vasco, VitoriaGasteiz, Eusko Jaurlaritza.

- (2007): Gizarteratzeko Erakunde Arteko II Plana 20072009, Vitoria-Gasteiz, Eusko Jaurlaritza.
- (2004): Pobreziaren eta Gizarte-desberdintasunen Inkesta, Vitoria-Gasteiz, Eusko Jaurlaritza.

- (1986): Pobreziaren eta Gizarte-desberdintasunen Inkesta, Vitoria-Gasteiz, Eusko Jaurlaritza.

LANBIDE (2010): Errenta Aktiboaren Plan Pilotuaren egoeraren informazioari buruzko txostena, Vitoria-Gasteiz, Eusko Jaurlaritza.

MARTÍNEZ TORRES, M. (2004): Los sistemas de rentas mínimas en España y la Unión Europea: un analisis comparado, Documentos de Trabajo de la Facultad de Ciencias Económicas y Empresariales saila, 13. zb. [<http://eprints. ucm.es/6837/ $/$ ].

MILANO, S. (1990): Los ingresos minimos garantizados en la CEE, Vitoria-Gasteiz, Eusko Jaurlaritza.

MONDRAGON, J. (2006): Análisis de políticas públicas contra la pobreza y la exclusión en la Comunidad Autónoma del País Vasco, Vitoria-Gasteiz, Herri Arduralaritzaren Euskal Erakundea.

MORENO MÁRQUEZ, G. (2009): “Realidad, presente y futuro de las políticas contra la exclusión social en el País Vasco", Revista Española del Tercer Sector, 12. zb., 41-71 or.

- (2008): Crisis y reconstrucción del Estado del bienestar, Vitoria-Gasteiz, Eusko Jaurlaritzaren Argitalpen Zerbitzu Nagusia.

- (2006): Herritartasuna berdefinitzen: Oinarrizko Errenta, Giza Eskubideak-Derechos Humanos saila, 41. zb., Bilbo, Deustuko Unibertsitatea.

NOGUERA, J. A.; eta UBASART, G. (2003): "Las políticas de rentas mínimas en las comunidades autónomas", in GALLEGO, R.; GOMÀ, R.; eta SUBIRATS, R. (koord.), Estado de bienestar y comunidades autónomas, Madril, Tecnos, 186-210 or.

OINARRIZKO ERRENTA SAREA (d.e.) [<http://www. redrentabasica.org/euskara/>].

SANZO, L.; eta PINILLA, R. (2004): La renta básica. Para una reforma del sistema fiscal y de protección social, Documentos de Trabajo saila, 42/2004. zb., Madril, Fundación Alternativas.

RAVENTÓS, D. (2008): La renta básica como derecho de existencia social [<http://www.ub.edu/ economiaempresa/cafe-forum/doc/CAFE/CafeForum_Daniel_Raventos_5-5-08.pdf)]

- (2007): Basic Income: The Material Conditions of Freedom, Londres, Pluto Press.

RODRÍGUEZ CABRERO, G. (2009): Valoración de los programas de rentas mínimas en España, EU Network of Independent Experts on Social Inclusion.

SARTU FEDERAZIOA (2010): Joera sozialak eta gizarteratzea / Tendencias sociales e inclusión social, Bilbo, Sartu Federazioa [<http://economiasolidaria. org/files/joera_sozialak_gizarteratzea.pdf)].

TEZANOS, J. F. (2004): Tendencias en desigualdad y exclusión social. Tercer Foro sobre Tendencias Sociales, Madril, Sistema.

VAN PARIJS, P.; eta VANDERBORGHT, Y. (2006): La renta basica: una medida eficaz contra la pobreza, Bartzelona, Paidós. 